NBER WORKING PAPER SERIES

\title{
EAT, DRINK, FIRMS AND GOVERNMENT: AN INVESTIGATION OF CORRUPTION FROM ENTERTAINMENT AND TRAVEL COSTS OF CHINESE FIRMS
}

\author{
Hongbin Cai \\ Hanming Fang \\ Lixin Colin Xu \\ Working Paper 11592 \\ http://www.nber.org/papers/w11592 \\ NATIONAL BUREAU OF ECONOMIC RESEARCH \\ 1050 Massachusetts Avenue \\ Cambridge, MA 02138 \\ August 2005
}

\begin{abstract}
We are grateful to Yang Jian for insights on accounting practices in Chinese .rms, and George Clarke, Robert Cull, Philip Keefer, Naomi Lamoreaux, Keun Lee, Enrico Moretti, Jean-Laurent Rosenthal, Dan Treisman and Christopher Udry for helpful discussions and comments. All remaining errors are ours. Contact Addresses: Cai, Department of Economics, UCLA, 405 Hilgard Avenue, Los Angeles, CA 90095-1477; Fang, Department of Economics, Yale University, P.O. Box 208264, New Haven, CT 06520-8264; Xu: Development Research Group, World Bank, 1818 H Street, Washington, DC 20433. The views expressed herein are those of the author(s) and do not necessarily reflect the views of the National Bureau of Economic Research.
\end{abstract}

(C)2005 by Hongbin Cai, Hanming Fang and Lixin Colin Xu. All rights reserved. Short sections of text, not to exceed two paragraphs, may be quoted without explicit permission provided that full credit, including () notice, is given to the source. 
Eat, Drink, Firms and Government: An Investigation of Corruption from Entertainment and Travel Costs of Chinese Firms

Hongbin Cai, Hanming Fang and Lixin Colin $\mathrm{Xu}$

NBER Working Paper No. 11592

August 2005

JEL No. L2, O1, H2

\section{$\underline{\text { ABSTRACT }}$}

Entertainment and Travel Costs (ETC) is a standard expenditure item for Chinese firms with an annual amount equal to about 20 percent of total wage bills. We use this objective accounting measure as a basis to analyze the composition of ETC and the effect of ETC on firm performance. We rely on the predictions from a simple but plausible model of managerial decision-making to identify components of ETC by examining how the total ETC responds to different environmental variables. In our empirical analysis we find strong evidence that firms. ETC consists of a mix that includes bribery to government officials both as "grease money" and "protection money," expenditures to build relational capital with suppliers and clients, and managerial excesses. ETC overall has a significantly negative effect on firm performance, but its negative effect is much less pronounced for those firms located in cities with low quality government service, those who are subject to severe government expropriation, and those who do not have strong relationship with suppliers and clients. Our findings have important implications on how to effectively curb corruption.

Hongbin Cai

Department of Economics

UCLA

405 Hilgard Avenue

Los Angeles, CA 90095-1477

cai@econ.ucla.edu

Hanming Fan

Department of Economics

Yale University

PO Box 208264

New Haven, CT 06520-8264

and NBER

hanming.fang@yale.edu

\section{Lixin Colin Yu}

Development Research Group

World Bank

1818 H Street

Washington, DC 20433

1xu1@worldbank.org 


\section{Introduction}

Corruption is one of the central issues in developing and transitional economies, as evidenced by the fact that the Copenhagen Consensus identified "Governance and Corruption" as one of the global priority proposals (see Rose-Ackerman [28]). There are at least two crucial necessary conditions in order to effectively curb corruption: first, we must have effective methods to detect corruption; second and probably more importantly, we must know the institutional determinants of corruption.

Yet due to its illicit nature corruption is notoriously difficult to detect with objective data. As a result, most of the existing literature on corruption relies either on micro-level subjective surveys or country-specific corruption perception indices (see, e.g. Ades and Di Tella [2], Mauro [19] and Treisman [29] for recent contributions and Bardhan [3] for a literature review). However, subjective survey data can suffer from a number of well-known biases (see, for example, Bertrand and Mullainathan [4] for a recent exposition).

Recently a small but growing literature has proposed new approaches to look for evidence of corruption. Olken [23] compares administrative data on the amount of rice distributed with survey data on the amount actually received by households to measure corruption in an anti-poverty program in Indonesia; similarly Olken [24] compares engineers' estimate of the construction costs and the actual book costs of road projects in Indonesia to provide objective measures of corruption. While objective measures of corruption is obviously most desirable, it is often costly to audit all public projects where corruption may occur. Moreover, corruption can occur in many situations where an objective assessment is not possible. In such cases researchers have attempted to rely on predictions from economic models for indirect evidence of corruption. For example, Duggan and Levitt [9] use a simple game-theoretical model highlighting the nonlinear incentive structure of promotion in Japanese sumo wrestling to analyze and find evidence of match rigging. Di Tella and Schargrodsky [8] use the negative correlation between hospital input prices in Buenos Aires and auditing intensity to infer that hospital procurement officers may be engaged in accepting bribes. Khwaja and Mian [16] examine the relationship between whether firms have politicians on their board and their loan amount as well as default rate to make indirect inference of corruption in Pakistan. Hsieh and Moretti [12] infer corruption in Iraqi's oil-for-food program from the underpricing of Iraqi oils.

While finding reliable and objective, albeit indirect, evidence of corruption is important, it is equally critical - from a public policy viewpoint - to understand the institutional causes and 
economic consequences of corruption. All economists agree that corruption results from weak institutions, however as argued in Acemoglu and Johnson [1], all weak institutions are not created equal. They proposed a dichotomy of "property rights" and "contracting institutions" and argued that weakness of the two sets of institutions lead to different responses between economic parties and imply different social consequences. ${ }^{1}$ Due to data limitations, empirical work has shed little light on the more detailed institutional causes of corruption. Moreover most of the existing empirical research on the effect of corruption typically focus on whether corrupt governments lower the rates of economic growth at the macro level (see, for example Mauro [19]). Unfortunately there is no systematic evidence regarding the private return to bribing government officials at the firm level. ${ }^{2}$

Our paper makes three contributions to the vast literature on corruption. First, in the spirit of Duggan and Levitt [9], we rely on the predictions from a simple behavioral model of Chinese managers and use indirect inference approach to detect corruption. Second, we empirically investigate various institutional determinants in firms' corruption decisions. Third, we examine how the private returns to firms from corruptive activities vary with institutional factors.

We use a unique data set of 3,470 Chinese firms in our empirical analysis. The main object of interest is "Entertainment and Travel Costs" (henceforth, ETC), which is a standard expenditure item in the accounting books of Chinese firms. The information about ETC in our data set is directly taken from firms' accounting books and thus is not subject to the biases associated with subjective survey data. As its name indicates, it is used to cover entertainment (including eating, drinking, gifts, Karaoke and sports club membership, etc.) and travel expenditures. ${ }^{3}$ Besides legitimate business travel and other expenses, Chinese firms commonly use the ETC accounting category to reimburse expenditures used to bribe government officials, clients and suppliers, or

\footnotetext{
1 "Property right institutions" are weak when firms are subject to expropriation by government officials or other individuals. Firms as a result may be forced to pay bribes in exchange for protection (or less expropriation). Corruption in such cases does not play a socially productive role. In contrast, "contracting institutions" are weak when governments do not provide high-quality services to facilitate trade, such as slow license approvals or erratic contract enforcement. Firms will be induced to bribe government officials to "greases the wheel." Corruption under such circumstances can increase social welfare by "making things work" in an otherwise rigid and stifling bureaucratic system (see for example, Lui [18] for a formal argument, and Kaufmann and Wei [15] for an empirical inquiry).

${ }^{2}$ Fisman and Svesson [10] is the only paper we are aware of that examines how bribery affects firm growth using firm-level data from Uganda. They rely on self-reported bribery payments in their analysis and find a strong negative effect of bribery payments on firm growth.

${ }^{3}$ See Washington Post August 22, 2005 for a report on how such practices affect U.S. multinationals operating in China.
} 
simply managerial excess. ${ }^{4}$ Fake or inflated receipts are submitted for reimbursement of illegitimate expenses. While the central government is aware of such practices, to prove that a particular expenditure is illegitimate is close to impossible, probably because in China it is still the norm to do business transactions in cash, thus such practices are de facto legal. On average each firm in our data sets spends $¥ 946,400$ (more than $\$ 110,000$ ) annually on ETC. ${ }^{5}$ The average ETC expenditures is about 20 percent of the average firm's total wage bill, about 2.6 percent of its total sales revenues and about 4.0 percent of its total value-added. ${ }^{6}$ Among all listed manufacturing firms in Korea, ETC expenditure is about 0.74 percent of their total sales in 2000-03. ${ }^{7}$ Thus as a percentage of total sales, Chinese firms in our sample spend about 2.5 times more on ETC than Korean manufacturing firms.

To infer from the total ETC expenditure about its components the key empirical challenge is that ETC likely contains both legitimate business expenses and corruptive expenses. Similar to the indirect inference approach of Duggan and Levitt [9], we develop a simple model of Chinese manager's decisions over how much to spend on three different categories of expenditures: (1) normal business expenditures (to build relationship capital with suppliers and clients); (2) corruption payments to government officials in exchange for lower expropriation and/or better service; (3) managerial excesses (e.g., taking family and friends to restaurants, clubs and travels at the firms' expense). The predictions from our model indicate that, ceteris paribus, if the expropriation by local government (proxied by effective tax rates) is responsive to bribery payments, total ETC will be higher for firms more prone to expropriation; similarly, if the quality of local government service is responsive to bribery payments, firms will bribe more in cities with lower quality of government service; in contrast, if local governments are not responsive to bribery payments in their expropriation levels or quality of service - thus firms will choose not to bribe at all - our model predicts that the total ETC will decrease in government expropriation and increase in government service quality. We also derive comparative predictions about how the total ETC is affected by corporate governance and firms' relational capital with clients and suppliers. We use these comparative stat-

\footnotetext{
${ }^{4}$ Such practice is not limited to China. Bodrock [5] documented similar cases in Ukraine.

${ }^{5}$ In this paper, we will use $¥$ as the symbol for Chinese Yuan.

${ }^{6}$ Our numbers are roughly consistent with estimates in the aggregate. Hu [13] estimates that in 1997 Chinese firms and government agencies spent more than $¥ 200$ billion (about $\$ 25$ billion) on eating and drinking, and another $¥ 284$ billion (about $\$ 34$ billion U.S.) on tourism and overseas travel. The total expenditure of $¥ 484$ billion accounts for about 6.5 percent of China’s GDP (about $¥ 7.4$ trillion).

${ }^{7}$ We thank Keun Lee who calculated this number from Korea Investors Services database.
} 
ics predictions as the basis of our empirical analysis to identify components of ETC by examining how ETC responds to different environmental variables that we construct for each firm.

We find that ETC is higher when government expropriation is more severe, and when the quality of government service is lower (Table 2). From the theoretical predictions of the model, these findings suggest that corrupt payments to government officials account for a significant portion of ETC. Moreover, they also suggest that firms pay bribes both to buy "protection" against government expropriation and to "grease the wheel" in buying government services.

These findings are further reinforced in our analysis of the effects of ETC on firm performance as measured by Profit/Sales Ratio (Tables 3) and TFP (Table 4). Overall, we find that ETC negatively affect firms' profitability and TFP, a result that is robust when we instrument a firm's ETC by its city- and district-industry averages to deal with endogeneity issues. This result in itself suggests that a big part of ETC is managerial excesses. This conclusion is corroborated by our finding that the negative effects of ETC on firm performance are much less pronounced in firms with better corporate governance, i.e. those firms with greater private ownership and those that have fired a manager in the previous four years.

More importantly, we find that the negative effect of ETC on firms' profit and TFP is significantly less pronounced for firms with higher tax burdens and for firms receiving poorer quality of local government service. These findings strongly suggest that components of ETC are spent as "protection money" to reduce government expropriation and "grease money" in exchange for better government service.

Our findings also suggest that a significant portion of ETC is used productively to build relational capital with suppliers and clients. Not surprisingly, we find that firms that sell their main products to other provinces spend more on ETC than those who do not, suggesting that ETC increase in the difficulties of maintaining long-distance relationships. ${ }^{8}$ More interestingly, we find that money spent on ETC tend to be more productive for firms with weaker relationships with their main suppliers and clients.

The remainder of the paper is structured as follows. In Section 2, we present a simple model to illustrate our identification strategy. Section 3 describes our data and presents descriptive statistics. In Section 4, we examine the determinants of total ETC expenditures. Section 5 investigates how ETC expenditures affect firm performance, and Section 6 concludes.

\footnotetext{
${ }^{8}$ However, some of this effect could arise because firms doing business in other provinces may have to pay additional bribes to government officials in those provinces.
} 


\section{A Theoretical Model and Identification Strategy}

In this section we propose a simple but plausible model of ETC spending by Chinese managers. The predictions from the model are the key to our empirical strategy to distinguish different components of ETC.

Consider a manager who decides the amount of firm funds to spend in three categories:

- Normal business expenditures, denoted by $x_{r}$, to build relational capital with suppliers and clients. This, among other things, includes travel expenses to meet suppliers and clients;

- Corruption payments (bribes) to government officials, denoted by $x_{b}$. We furthermore divide $x_{b}$ into two sub-components: bribes in exchange for government services - the "grease money" - is denoted by $x_{g}$; and bribes in exchange for lower government expropriation - the "protection money" - is denoted by $x_{p}$. We can also think of $x_{g}$ as bribes to service-related government agencies such as licensing and utilities etc. and $x_{p}$ as bribes to tax agencies. Of course $x_{b} \equiv x_{g}+x_{p}$

- Managerial excess, denoted by $x_{c}$, that goes directly to the manager's own pocket or to his/her family and friends.

By definition, the private consumption $x_{c}$ is simply a deduction from firm profit. The bribes to government officials $\left(x_{g}\right.$ and $\left.x_{p}\right)$, as well as the relational investment $x_{r}$, however, may have a positive effect on firm's profit. We now detail how $x_{g}, x_{p}$ and $x_{r}$ affect firm performance.

We assume that the firm has a potential profit opportunity $Q>0 .{ }^{9}$ The probability that $Q$ can be realized, or, equivalently, how much of $Q$ can be realized, is denoted by $q\left(K_{g}, K_{r}\right)$, where $K_{g}$ is the actual quality of service a firm receives from the government, and $K_{r}$ is the firm's actual relational capital with its suppliers and clients. Our interpretation is that the firm needs the cooperation from both the government officials and from the firm's suppliers and clients in order to realize potential profit opportunities. We make the following natural assumptions about function $q(\cdot, \cdot)$ :

Assumption 1: $q(\cdot, \cdot)$ is strictly increasing and concave in both arguments; moreover, $K_{g}$ and $K_{r}$ are complements, i.e., $\partial^{2} q / \partial K_{g} \partial K_{r}>0$.

\footnotetext{
${ }^{9}$ In our empirical analysis, $Q$ will be approximated by a function of firm characteristics including its age, size, location and industry affiliation.
} 
The "grease money" bribes to government officials $x_{g}$ and the relational investment expenditure on suppliers and clients $x_{r}$ affect firm performance through their effect on $K_{g}$ and $K_{r}$. Let $K_{g}^{0}$ be the baseline quality of service from the government with no additional "grease money" bribes; and $K_{r}^{0}$ be the baseline level of the firm's relational capital with its suppliers and clients, which measures the cooperation that the firm can expect from them without any additional relational investment. We assume that $x_{g}$ and $x_{r}$ affect $K_{g}$ and $K_{r}$ respectively as follows:

$$
\begin{aligned}
& K_{g}=K_{g}^{0}+a_{g} x_{g}, \\
& K_{r}=K_{r}^{0}+a_{r} x_{r},
\end{aligned}
$$

where the parameters $a_{g} \geq 0$ and $a_{r} \geq 0$ measure the effectiveness of these expenditures.

The "protection money" bribe $x_{p}$ affects the level of government expropriation as measured by the firm's effective tax rate $t$. A parsimonious but plausible way to model how much taxes a Chinese firm typically pays is that it depends on three factors:

- The official tax rate for the firm's type, denoted by $t_{0}$;

- The baseline government expropriation in the absence of any additional bribe to the government officials, denoted by $K_{p}^{0}$. Presumably $K_{p}^{0}$ itself depends on both the general level of expropriation of the city government and the bargaining power of the firm;

- The firm's "protection money" bribes, denoted by $x_{p}$, to tax-related government agencies in exchange for lower expropriation.

We assume that the local government will impose an effective tax rate $t\left(x_{p} ; K_{p}^{0}, t_{0}\right)$ on the firm. More specifically, we assume that

$$
t\left(x_{p} ; K_{p}^{0}, t_{0}\right)=t_{0} r\left(K_{p}\right)
$$

where $K_{p}$ is the actual level of government expropriation and it is affected by "protection money" bribes $x_{p}$ as follows:

$$
K_{p}=K_{p}^{0}-a_{p} x_{p}
$$

where $a_{p} \geq 0$ measures the effectiveness of the firm's bribes $x_{p}$ in reducing government expropriation. We assume that:

Assumption 2: $r(\cdot)$ is strictly increasing and concave. 
Thus, if a manager chooses the vector $\left\{x_{c}, x_{r}, x_{g}, x_{p}\right\}$, the firm's net profit for the period is given by:

$$
\Pi\left(x_{c}, x_{r}, x_{g}, x_{p}\right)=\left[1-t\left(x_{p} ; K_{p}^{0}, t_{0}\right)\right] q\left(K_{g}, K_{r}\right) Q-\left(x_{c}+x_{r}+x_{g}+x_{p}\right) .
$$

It is worth noting that here we make the simplifying assumption that the tax base for Chinese firms is revenue instead of gross profit. ${ }^{10}$

We assume that the "owner" of the firm observes only the total net profit $\Pi$ and managerial excess $x_{c}$, but cannot directly distinguish the other elements of ETC expenses $x_{r}, x_{g}, x_{p} \cdot{ }^{11,12}$ The firm "owner" decides whether to retain the manager at the end of the period based on the current period net profit and the observed managerial excess $x_{c}{ }^{13}$ The probability that the manager will be retained for the next period is assumed to be:

$$
\rho\left(\Pi, x_{c} ; \beta_{\pi}, \beta_{c}\right)=1-\tau e^{-\left(\beta_{\pi} \Pi-\beta_{c} x_{c}\right)},
$$

where the parameters $\tau \in(0,1), \beta_{\pi}>0$ and $\beta_{c}>0$ measure the corporate governance of the firm: $\tau$ can be considered as the natural rate of managerial turnover; higher values of $\beta_{\pi}$ imply that the manager is to a greater degree held responsible for the firm's financial performance; and higher values of $\beta_{c}$ means better monitoring of managerial excess. ${ }^{14,15}$ The function $\rho\left(\cdot, \cdot ; \beta_{\pi}, \beta_{c}\right)$ nicely captures the idea that the manager is more likely to be retained if he makes a higher profit and indulges in less managerial excess.

\footnotetext{
${ }^{10}$ This assumption is much closer to reality that an alternative assumption that the tax base is net profit. In our sample, many firms had net losses (in fact, the average profit over total sales is about -8.8 percent) yet they all paid positive taxes.

${ }^{11}$ By firm "owner" we mean the party in the firm who decides on hiring and firing top managers. For corporations, this means the boards of directors; for state-owned firms, this means the government bureau supervising the firm; and for privately owned firms, it is the owner of the firm.

${ }^{12}$ A more realistic assumption that the "owner" of the firm observes only a noisy signal of managerial excess $x_{c}$ does not change the qualitative results.

${ }^{13}$ We abstract away from explicit incentive contracts for simplicity. Adding some profit-sharing, as long as it is not too large, in the manager's payoff function will not change the qualitative results of the model, but can substantially complicate the analysis.

${ }^{14}$ If managerial excess $x_{c}$ is observed with noise, then the precision of the signal (which measures the owner's monitoring technology) will appear in parameter $\beta_{c}$.

${ }^{15}$ We implicitly assume here that firm owners face various constraints (such as verifiability, enforceability and legal constraints, etc.) in designing the incentive systems for their managers; and thus $\beta_{\pi}$ and $\beta_{c}$ represent the optimal solution under those constraints.
} 
Finally, let $V>0$ be the manager's continuation value from being retained and let $\delta \in(0,1)$ be his discount factor. The manager's problem is to choose $\left\{x_{c}^{*}, x_{r}^{*}, x_{g}^{*}, x_{p}^{*}\right\}$ to maximize:

$$
U\left(x_{c}, x_{r}, x_{g}, x_{p}\right)=x_{c}+\delta \rho(\overbrace{\left[1-t\left(x_{p} ; K_{p}^{0}, t_{0}\right)\right] q\left(K_{g}, K_{r}\right) Q-\left(x_{c}+x_{r}+x_{g}+x_{p}\right)}^{\text {Net Profit } \Pi}, x_{c} ; \beta_{\pi}, \beta_{c}) V .
$$

The main prediction of the model is summarized in Proposition 1 whose proof is relegated to Appendix A.

\section{Proposition 1 (Identification of ETC Components)}

A1. For $i \in\{r, p, g\}, x_{i}^{*}=0$ if $a_{i}=0$;

A2. For $i \in\{r, g\}$, the total ETC is increasing in $K_{i}^{0}$ if $a_{i}=0$;

A3. If $a_{p}=0$, the total ETC is decreasing in $K_{p}^{0}$.

B1. For $i \in\{r, p, g\}, x_{i}^{*}>0$ if $a_{i}$ is positive and sufficiently large;

B2. For $i \in\{r, g\}$, the total ETC is decreasing in $K_{i}^{0}$ if $a_{i}$ is positive and sufficiently large;

B3. The total ETC is increasing in $K_{p}^{0}$ if $a_{p}$ is positive and sufficiently large.

Proposition 1 is the key prediction of the model that we rely on to identify the ETC components. If, for example, the "grease money" $x_{g}$ is not an important component of the firm's ETC (i.e., $a_{g}=0$ ), Part A2 of Proposition 1 indicates that the firm's total ETC expenditure should be increasing in $K_{g}^{0}$, which as we explain above measures the baseline quality of government service. On the other hand, if $x_{g}$ is indeed an important component of the firm's ETC (i.e., $a_{g}$ is positive and sufficiently large), Part B2 of Proposition 1 indicates that we should expect the firm's total ETC to be decreasing in $K_{g}^{0}$. The distinct effects of $K_{r}^{0}$ and $K_{p}^{0}$ on the firm's total ETC expenditures are similar. To the extent that we can empirically observe the firm's total ETC and find reasonable proxies for $K_{r}^{0}, K_{g}^{0}$ and $K_{p}^{0}$, we can empirically verify whether $a_{i}$ is zero or sufficiently positive for $i \in\{r, p, g\}$. This is exactly our empirical strategy.

Identification of managerial excess $x_{c}$ is somewhat different. In fact, our specification of the manager's payoff function (7) assumes that the manager will always choose a positive level of $x_{c}$. Let us consider how managerial incentive intensity represented by the corporate governance variable $\beta_{\pi}$ and $\beta_{c}$ in the model affects total ETC expenditure. Suppose $\beta_{\pi}$ and $\beta_{c}$ are both positive, then from 
the proof of Proposition 1 in Appendix A, $x_{p}^{*}, x_{r}^{*}, x_{g}^{*}$ are all independent of $\beta_{\pi}$ and $\beta_{c}$. However, $x_{c}^{*}$ is decreasing in $\beta_{c}$ (see Equation 12 noting that the cash flow $\varphi^{*}$ is independent of $\beta_{c}$ ). Thus the total ETC is decreasing in $\beta_{c}$. In contrast $x_{c}^{*}$ can be either decreasing in $\beta_{\pi}$ (when $\beta_{\pi}$ and $\varphi^{*}$ are relatively small), or increasing in $\beta_{\pi}$ (when $\beta_{\pi}$ and $\varphi^{*}$ are relatively large). The reason for the latter is that if profit is weighted heavily in managerial retention, then a manager may choose a higher managerial excess once the cash flow is high, since his job will likely be secure. Thus, our model makes an ambiguous prediction about how the total ETC is affected by the firm's $\beta_{\pi}$.

Proposition 2 summarizes the model's implications about the firm's net profit. It is proved formally in Appendix B.

Proposition 2 (Firm Performance) The optimal net profit $\Pi^{*}$ is increasing in $K_{r}^{0}$ and $K_{g}^{0}$, and decreasing in $K_{p}^{0}$.

Because the predictions in Proposition 2 do not depend on whether $a_{i}, i \in\{r, p, g\}$ is zero or sufficiently positive, Proposition 2 does not provide a direct test of the importance of ETC components. But evidence consistent with it certainly lends support to our model as a whole.

\subsection{Discussions of Modelling Assumptions}

We made an important linearity assumption in the specifications of the "production equation" for $K_{g}, K_{r}$ and $K_{p}$ [see Equations (1), (2) and (4)]. While admittedly restrictive, this type of accumulation technology is commonly used especially in the economic growth literature. The qualitative results of our model should still hold, though not as clean, if the actual accumulation technologies are approximately but not exactly linear.

In our model we focused on the manager's single-period decision problem with the continuation payoff modelled as a constant $V$. Presumably dynamic considerations are pertinent when parts of ETC expenditures are equivalent to investments in long-term relationships with the government officials, suppliers and clients. The formulation of the manager's dynamic optimization problem in (7) is valid only in a stationary world. This modelling assumption is partly for simplicity and partly out of necessity because we only have one-period information on Entertainment and Travel Costs for the firms in our data.

We illustrated our identification strategy by considering a representative Chinese firm. In empirically implementing the identification strategy, we rely on cross-firm variations in many dimensions. In fact firm heterogeneity is the source of variations that allows us to test Proposition 1. For example, as we mentioned in footnote 9 , firms' profit opportunities $Q$ are allowed to vary by city, 
industry, size, age, and market coverage. Firms also vary greatly in their $K_{g}^{0}, K_{p}^{0}, K_{r}^{0}$ and corporate governance structure.

\section{Data and Measurements of Key Variables}

\subsection{Two Firm-Level Surveys}

Our data come from two firm-level surveys conducted jointly by the World Bank and the Enterprise Survey Organization of China. The first survey, fielded during 2000-02, covers 2,400 firms from 18 cities, representatively located across five regions of China. The second survey covers 1,070 firms located in 15 cities of Liaoning Province during 2001-03. Two cities in Liaoning Province, Benxi and Dalian, appear in both surveys, so there are 31 cities in total in the two surveys. Figure 1 shows the geographic coverage of the first survey, and indicates the location of Liaoning province. It also groups the 18 cities in the first survey into five regions. The other 13 cities in Liaoning Province in the second survey are not depicted in Figure 1.

\section{[Figure 1 About Here]}

In the first survey, either 100 or 150 firms were randomly sampled for each city from an electronic database of firms subject to the following constraints. First, firms are selected to ensure that both manufacturing and service industry firms are adequately represented. ${ }^{16}$ Second, only firms that satisfy minimum size requirement (measured by number of employees) are sampled. ${ }^{17}$ The second survey covered all major cities in Liaoning Province. 80 firms were sampled in the cities of Shenyang and Dalian, the two largest cities in the province, and 70 firms were sampled in all other 13 cities. ${ }^{18}$ The two surveys cover a combined total of 3,470 firms located in 31 cities that are at very different

\footnotetext{
${ }^{16}$ The manufacturing industries include apparel and leather goods, electronic equipment, electronic components, consumer products, vehicles and vehicle parts. The service industries include accounting and related services, advertising and marketing, business logistics services, communication services, and information technology services.

${ }^{17}$ The minimum number of employees for firms in the sample is 20 in manufacturing industries and 15 in service industries. The size criterion was loosened when there were not enough firms from a particular sector in a city. As a result, roughly 3 percent of firms in our sample have less than 15 employees.

${ }^{18}$ The 13 other cities are Dalian Deveopment Zone, Anshan, Fushun, Benxi, Dandong, Jinzhou, Yingkou, Fuxin, Liaoyang, Tieling, Chaoyang, Pangjin, Huludao. We treat Dalian Development Zone as a separate city because it has relatively autonomous status and is significantly different from Dalian in general. The sample of firms in Dalian Development Zone is drawn independently from the firms in Dalian.
} 
stages of economic development. Within this sample of cities, GDP per capita (in 2002 value) ranges from $¥ 3400$ to $¥ 46,400$ (equivalently to about $\$ 400$ to $\$ 5,000$ ).

The questionnaires for the two surveys are identical for the variables we use in our analysis and they consist of two parts. ${ }^{19}$ The first part is filled out by firms' senior managers and asks for qualitative information on the firm; the second part covers financial and quantitative information about the firms' production and operation, and is obtained from personal interviews with the firm's chief accountant. Our data sets thus contain detailed information about firm characteristics and performance. the average (median) firm in our sample has 572 (112) employees, and has been in business for 15 (9) years. Its annual total sales revenue is about $¥ 191$ (9.4) Million. While the average firm makes a loss equal to approximately 10 percent of its total sales, the median firm makes a meager profit of .4 percent of its total sales. ${ }^{20}$ Close to 60 percent of the firms in our sample sell their main products to other provinces.

\subsection{Measurement of Key Variables}

Measurement of ETC. The first variable of central interest is Entertainment and Travel Costs. This is a readily available category in the accounting book of every firm and obtained from the second part of the survey with the firm's chief accountant. These expenditures are measured with little error because each reimbursement item in this category needs a "receipt." Entertainment and Travel Costs are supposedly for the purpose of reimbursing expenses related to conducting normal businesses. However, accounting practice in China is sufficiently lax so that managers may get reimbursed for almost any kind of entertainment and travel for any purpose, often with fake or inflated receipts.

Entertainment and Travel Costs represent a significant portion of firms' expenditures. The ratio of Entertainment and Travel Costs to Total Wage Bill at the firm level has a median of 8.8 percent, and a mean of 19 percent. ${ }^{21}$ The ratio of Entertainment and Travel Costs to Value-Added

\footnotetext{
${ }^{19}$ The survey instrument is available from the authors upon request.

${ }^{20}$ The widespread losses among the sampled firms may be related to genuine losses in state-owned firms and more profit hiding (see Johnson, et al [14] and Cai, et al [7]). Due to data limitations we are unable to examine whether profit hiding is correlated with the variables used in our analysis. Thus our results in Section 5 need to be interpreted with caution. The other measure of firm performance, productivity, estimated from value-added or total sales data, is more immune to these problems and hence more reliable. As will be shown later, we reach similar qualitative conclusions whether we measure firm performance by profitability or by productivity.

${ }^{21}$ We exclude the firms whose Entertainment Travel Cost/Total Wage Bill ratio is among the top 5 percentile in calculating this mean to ensure that our calculation is not driven by outliers.
} 
has a median of 1.8 percent and a mean of 4.0 percent. In our empirical analysis, we normalize Entertainment and Travel Costs by Total Sales, and from now on the term ETC refers to the Entertainment and Travel Costs/Total Sales ratio. In our data ETC has a median of 1 percent, and a mean of 2.6 percent. ${ }^{22}$ ETC also varies substantially across firms, with a sample standard deviation of 6.2 percent.

Across cities, the firm average of ETC ranges from 0.8 percent in Jiangmeng, a coastal and relatively affluent city, to 5 percent in Guiyang, an inland and relatively backward city. Panel A of Figure 2 shows a clear negative relationship between the average ETC (ETC averaged over firms in the city) and the logarithm of the city's per capita GDP. ${ }^{23}$

[Figure 2 About Here]

Measurement of $K_{g}^{0}$. Our identification strategy presented in Section 2 relies on the empirical relationship between ETC and key environment variables $K_{g}^{0}, K_{p}^{0}$ and $K_{r}^{0}$. Here and below we describe how these variables are proxied in our empirical analysis. Recall that $K_{g}^{0}$ is meant to capture the baseline quality of government service in the absence of additional bribes. We proxy $K_{g}^{0}$ for each firm in our data by the manager's answer to the following question: "Among the government officials that your firm regularly interacts with, what is the percentage that tends to help the firm develop?" The answer to this question reflects the firm's evaluation of the tendency of government officials to help them; hence we will hereafter call this variable "Government Help." Higher level of "Government Help" implies higher $K_{g}^{0}$. "Government Help" is a firm-specific measure of government helpfulness that depends on the overall government quality and the lagged relational capital each firm has with government officials. Panel B of Figure 2 graphs average ETC against average "Government Help" measure for all cities in our data. Note that by construction the average "Government Help" in a city is bounded between zero and one, and it differs greatly across the cities with a mean of .364 and standard deviation of .334. Panel B illustrates that firms tend to spend less on ETC in cities in which the government is perceived to be more helpful.

Measurement of $K_{p}^{0}$. Recall that $K_{p}^{0}$ is the baseline government expropriation in the absence of any additional bribe to the government officials. For each firm we proxy $K_{p}^{0}$ by its "Total Tax Burden in the Previous Year," as measured by total taxes divided by sales in the previous year. This

\footnotetext{
${ }^{22}$ Firms with ETC at the top 0.5 percentile (a total of 19 firms) are excluded in calculating the mean to ensures that our calculation is not driven by outliers.

${ }^{23}$ The data used in all graphs in Figure 2 are reported in Table A1.
} 
variable represents the extent of government expropriation if the manager does not give additional bribes to government officials. This variable is taken from surveys with firm accountants. Unique features of Chinese tax system generate a substantial amount of across-firm variation in the tax burdens. Since Chinese firms pay both a central government and a local government tax, the first reason for tax burden variation is that the central government tax rates differ across firm types (e.g., tax incentives to attract foreign investments) and across regions (e.g., negotiations between the central government and provinces, tax reductions for special economic zones). Second, within the same city the local government often imposes different levels of local taxes. Third, tax law enforcement and collection efforts differ greatly across cities and across firms within each city, so a firm's actual tax burden depends on the vigilance level of local tax officials and the firm's relationship with them. These reasons explain why the actual tax burden varies so greatly across cities and across firms in the same city. Firms in our sample on average paid taxes equal to 7.2 percent of their total sales, with a standard deviation of 10.1 percent. The lowest average tax rate is Shenzhen's 4.6 percent, and the highest is Guiyang's 10.9 percent.

Panel $\mathrm{C}$ of Figure 2 plots average ETC against the average tax burden in the previous year at the city level. The graph shows a strong positive relationship, suggesting that ETC may be used to cushion the blunt of government expropriations.

Measurement of $K_{r}^{0}$. To measure a firm's baseline relational capital with its suppliers and clients $K_{r}^{0}$, we construct a variable called "Years of Relationship," which is the sum of the years that the firm has known its most important supplier and the years that it has known its most important client. This variable shows substantial variation across cities, with a low of 7 years in Lanzhou on average to a high of 9.1 years on average in Dandong. The sample mean is 8.3 years, and the sample standard deviation is 2.1 years. Proposition 1 indicates that if managers use entertainment expenditures to build contracting relationships with their suppliers and clients, ETC should be negatively correlated with "Years of relationship;" otherwise, ETC and "Years of Relationship" should be positively correlated. Panel D of Figure 2 plots ETC against the logarithm of "Years of Relationship." The slope is small but negative.

Measurement of Corporate Governance/Managerial Incentives. In our theoretical framework, corporate governance/managerial incentive parameters $\beta_{c}$ and $\beta_{\pi}$ both affect the manager's ETC expenditure. However the incentive structure for managers in Chinese firms is not at all 
transparent, and no good data are available on managerial incentives. ${ }^{24}$ We use two measures of corporate governance to gauge how a manager's incentives are aligned with those of the firm. The first is "Private Ownership," which measures the share of a firm owned by private parties, both domestic and foreign. Private owners are more motivated by profits and are thus likely to have stronger incentives to monitor managers' behavior. In our sample, the share of private ownership varies across firms from 0 (purely state-owned) to 1 (purely private), and the average firm in our sample has 35 percent of private ownership, with a standard deviation of 45.5 percent. The city averages vary from 81 percent in Wenzhou, a coastal city known for its private enterprises, to less than 17 percent in Fushun and Shenyang, two Northeastern cities. Panel E of Figure 2 plots average ETC against private ownership at the city level, revealing a weak relationship between them.

The second proxy of managerial incentives is a dummy variable indicating whether any senior manager (including general managers and deputy managers) had been fired in the previous four years, which we call "Managerial Dismissal." One expects that the incidence of senior manager dismissal indicates strong monitoring of top managers and hence greater pressure on current managers to improve firm performance. In our sample, 19 percent of firms fired a senior manager in the four years prior to the interview. There is substantial variation in this variable across cities. In the city of Yingkou, for example, 33 percent of the firms fired a manager in the previous four years, while only 7 percent of the firms in the city of Lanzhou did so. Panel F of Figure 2 does not show a clear relationship between managerial dismissal and ETC.

Other Variables. We also include in our empirical analysis basic firm characteristics such as the number of employees, firm age, and whether the firm sells to other provinces. Table 1 lists the detailed definition of each variable and its mean and standard deviation.

[Table 1 About Here]

\section{What Firms Spend More ETC?}

In this section, we empirically examine the determinants of ETC, using regression specifications suggested by our simple model in Section 2. The dependent variable is the ETC, and the list of explanatory variables varies by specification. For each regression specification we only use the sample of firms for which there are no missing values for any of the explanatory variables. For each

\footnotetext{
${ }^{24}$ The main reason is that most firms in our sample are not public firms, so they do not have to disclose compensations for managers.
} 
firm, we use the data from the last year in the respective survey because the Entertainment and Travel Cost is observed only for the last year. The specification we estimate is

$$
E T C_{i j c}=\alpha_{1 j} I N D_{j}+\alpha_{2} X_{c}+\boldsymbol{\alpha}_{3} \mathbf{Z}_{i}+\boldsymbol{\alpha}_{4} \mathbf{X}_{i}+\epsilon_{i j c}
$$

where the subscripts $i j c$ stands for firm $i$ in industry $j$ located in city $c$. We include industry dummy $I N D_{j}$ to filter out industry-specific needs for normal business expenditures in ETC; $X_{c}$ is a citylevel variable aimed to control for various aspects related to economic development. Depending on specifications, $X_{c}$ will either be the logarithm of the per capita GDP of the city where firm is located, denoted by $\ln \left(G D P_{-} P C_{c}\right)$, or simply a city dummy. The vector $\mathbf{Z}_{i}$ is a list of basic firm characteristics including firm size (logarithm of the number of employees), age (logarithm of $1+$ firm age), and whether it sells to other provinces; the vector $\mathbf{X}_{i}$ includes the variables discussed in the above section: "Government Help" (proxying $K_{g}^{0}$ ), "Total Tax Burden in the Previous Year" (proxying $K_{p}^{0}$ ), "Years of Relationship" (proxying $K_{r}^{0}$ ), "Private Ownership" and "Managerial Dismissal" (proxing for corporate governance).

[Table 2 about Here]

Table 2 presents the basic results from a series of OLS regressions. Column (1) presents the results from the simplest regression with only controls of basic firm characteristics and $\ln \left(G D P \_P C_{c}\right)$. We gradually add more and more controls in Column (2) to Column (6). In Column (7) we include city dummies instead of $\ln \left(G D P_{-} P C_{c}\right)$ to more flexibly control for city characteristics. ${ }^{25}$ Since the estimates from different specifications differ little, we shall focus our discussion on the complete specifications reported in column $(6) .{ }^{26}$

Our results show that larger firms, as measured by the number of employees, incur lower ETC. A one standard deviation increase in the logarithm of number of employees (1.48, see Table 1) reduces ETC by about .9 percentage points, which is a 35 percent reduction for ETC considering that the mean in our sample for ETC is 2.6 percentage points. This suggests that entertainment and travel costs exhibit strong economies of scale. In all specifications we do not find a robust relationship between ETC and firm age.

\footnotetext{
${ }^{25}$ Since $\ln \left(G D P_{-} P C_{c}\right)$ is embedded in the city dummies, we cannot include this variable in the column (7) when city dummies are included.

${ }^{26} \mathrm{~A}$ comparison of the coefficient estimates across Columns (1) to (6) show remarkable stability, indicating that multicollinearity is not a serious issue.
} 
We find that firms in cities with higher per capita GDP tend to have lower ETC, consistent with the raw correlation demonstrated in Panel A of Figure 2. The coefficient estimate suggests that a one standard deviation increase in log per capita GDP (0.46, see Table 1$)$ reduces ETC by .2 percentage points, or 8 percent reduction of the mean ETC level of .026.

In specification reported in Column (6) we find that the proxy for $K_{g}^{0}$ - "Government Help" reduces ETC, consistent with the raw correlation reported in Panel B of Figure 2. A one standard deviation increase in "Government Help" decrease ETC by .2 percentage points. By the identification results in Proposition 1, this suggests that part of ETC is spent to entertain or bribe government officials in exchange for higher quality of government services, thus providing support for the "grease money" view of corruption.

We find that the proxy for baseline government expropriation $K_{p}^{0}$, "Tax Burden in the Previous Year," has a strong and positive effect on ETC. This confirms the positive raw correlation between lagged tax burden and ETC depicted in Panel $\mathrm{C}$ of Figure 2. In the specification reported in Column (6), "Tax Burden in the Previous Year" is significant at the 5 percent level; and it implies that a one standard deviation increase in this variable will increase ETC by 38 percent. Again from Proposition 1, this evidence suggests that part of ETC is spent as "protection money" bribes to government officials in exchange for lower expropriation. ${ }^{27}$

We find that the variable "Years of Relationship" proxing for baseline relational capital with its suppliers and clients $K_{r}^{0}$ has a negative, though statistically insignificant, effect on ETC. However, we do find that firms that sell to other provinces tend to have higher ETC. Other things being equal, ETC in firms that sell to other provinces is .4 percentage points higher than that in firms that do not. By Proposition 1, these findings are consistent with the view that managers also use ETC to conduct normal business and to build relationships with suppliers and clients.

Our findings regarding the effect of corporate governance variables are mixed. "Private Ownership" does not have a robust and statistically significant effect on ETC. However, we find that "Managerial Dismissal" has strong and positive effects on ETC. The coefficient estimate is statistically significant across various specifications, and the magnitude is large: ETC in firms that fired at least one senior manager in the previous four years is .8 percentage point higher than that in those firms that did not, accounting for a 31 percent increase relative to the mean ETC of 2.6 percentage points. If a firm that had fired a senior manager before indeed has better corporate governance, this

\footnotetext{
${ }^{27}$ Given that we control for city level characteristics and the firm's industry, it is reasonable that the random shocks a firm experiences each period are serially independent. Under this assumption the lagged tax burden will be independent of $\epsilon_{i j c}$.
} 
finding is consistent with our model for the case of large $\beta_{\pi}$ (the weight on profit in the managerial evaluation system) and large $\varphi$ (expected cash flow). It is also possible that managers at these firing firms tend to spend entertainment on productive uses much more than their peers at firms with poor corporate governance. This interpretation is reinforced by our results, to be presented later, that ETC has a significantly more positive effect on firm performance when the firm has fired a senior manager.

The coefficient estimates when we use city dummies to control for city-level characteristics are reported in Column (7). The only noticeable difference in the coefficient estimate between the specification in Column (6) and (7) is that the coefficient of "Government Help" variable becomes slightly less negative (from -.006 to -.004) and is no longer statistically significant, with a $t$-statistics of 1.33. This is to be expected because "Government Help" has a non-negligible city-specific dimension. ${ }^{28}$

Finally we would like to investigate whether ETC, particularly the managerial excess $x_{c}$ component of ETC, is deliberately a substitute for regulated CEO pay, and it is part of the optimal CEO incentive structure. To evaluate this hypothesis, Column (8) reports the regression results from a specification in which we include two measures of CEO relative compensation: the first is the logarithm of the ratio of CEO wages to the firm's average wage; and the second is the logarithm of the ratio of the CEO wages to the average wage of the firm's mid-level managers. These ratios measure how well the CEOs are paid. Higher ratios would indicate that ETC is less likely a part of the implicit CEO pay. If the implicit CEO pay hypothesis is true, we would expect a statistically significant negative relationship between these relative wage ratios and ETC. The results in Column (8) does not support the view that ETC is entirely a form of CEO pay because ETC is not statistically correlated with either relative wage measure.

To summarize, in light of the identification strategy developed in Proposition 1, regression results we presented in Table 2 strongly support the view that ETC consists of multiple components among Chinese firms. It certainly is related to normal business travel and (weakly) related to the building of relational capital with suppliers and clients. It includes both "grease money" bribery to obtain better quality of government service and "protection money" bribery in exchange for lower tax burdens. The evidence does not support the hypothesis that ETC is a substitute for regulated CEO pay.

\footnotetext{
${ }^{28}$ When we regress "Government Help" on city dummies, the $R^{2}$ is .173 . Therefore, there are clearly both firmspecific and city-specific dimensions to the "Government Help" variable.
} 


\section{$5 \quad$ ETC and Firm Performance}

In this section, we examine the impact of ETC on firm performance to shed further light on the nature of ETC. Because ETC expenditures are chosen by the firm managers, we expect the marginal effect of ETC on firm performance to respond to the proxy variables "Government Help" (for $K_{g}^{0}$ ), "Tax Burden in the Previous Year" (for $K_{p}^{0}$ ), "Years of Relationship" (for $K_{r}^{0}$ ) and the corporate governance proxies "Private Ownership" and "Managerial Dismissal." To the extent that some components of ETC are chosen to improve government quality service, to lower government expropriation, and to strengthen relationship with suppliers and clients, our theory naturally predicts that the returns to ETC should be higher when "Government Help" (proxying $K_{g}^{0}$ ) and "Years of Relationship" (proxying for $K_{r}^{0}$ ) are low, and "Tax Burden in the Previous Year" (for $K_{p}^{0}$ ) is high; moreover, we also expect that firms with better corporate governance should exhibit higher returns to ETC because ETC in these firms is more likely spent to improve firm performance instead of managerial excesses.

To test the above implications on the effect of ETC on firm performance, we estimate the following two regression equations:

$$
\begin{aligned}
& Y_{i j c}=\beta_{1 j} I N D_{j}+\beta_{2} X_{c}+\boldsymbol{\beta}_{3} \mathbf{Z}_{i}+\boldsymbol{\beta}_{4} \mathbf{X}_{i}+\beta_{5} E T C_{i}+\mu_{i j c}, \\
& Y_{i j c}=\gamma_{1 j} I N D_{j}+\gamma_{2} X_{c}+\gamma_{3} \mathbf{Z}_{i}+\gamma_{4} \mathbf{X}_{i}+\gamma_{5} E T C_{i}+\gamma_{6} E T C_{i} \times \mathbf{X}_{i}+\sigma_{i j c}
\end{aligned}
$$

where the dependent variable $Y_{i j c}$ is a performance measure for firm $i$ in industry $j$ located in city $c$. In our empirical analysis we focus on two performance measures. The first is the ratio of profit over sales (POS henceforth) and the second is the firm's total factor productivity (TFP henceforth). ${ }^{29}$ The vector of firm level characteristics $\mathbf{Z}_{i}$ and $\mathbf{X}_{i}$ are the same as in the previous section. Both regression specifications (9) and (10) estimate the effect of $\mathbf{X}_{i}$ variables on firm performance, allowing us to directly test the predictions of Proposition 2; it also estimates how ETC affects firm performance. However, by including interaction terms of ETC and the key $\mathbf{X}_{i}$ variables, specification (10) estimates how the private returns to ETC vary with the environmental variables in the vector $\mathbf{X}_{i}$. In this specification the effect of ETC on firm performance $Y_{i j c}$ depends on $\mathbf{X}_{i}$ because $\partial Y_{i j c} / \partial E T C_{i}=\gamma_{5}+\gamma_{6} \mathbf{X}_{i}$.

\footnotetext{
${ }^{29}$ We estimate the firm's TFP using various empirical methods in the empirical productivity literature. Table 4 below uses TFP estimates from running log of valued added on logs of capital stock and labor, both interacted with industry dummies, and allowing for industry-specific intercepts. That is, we estimate industry-specific production functions. We also report almost identical results using alternative estimates of TFP below.
} 
Before we present the estimation results, we note that ETC is an endogenous variable. If there are omitted factors that affect both a firm's ETC and its performance, the OLS estimates will be inconsistent. In the GMM specifications we report below, for each firm $i^{\prime} s$ ETC we create three instruments: the first is the average ETC in firm $i^{\prime} s$ city and industry; the second is square of the city-industry average; and the third is the average ETC in firm $i^{\prime} s$ district and industry. ${ }^{30,}{ }^{31}$ We exclude firm $i^{\prime} s$ own ETC in computing both the city- and district-industry averages. The choice of the instruments is justified by our theoretical model. In Section 2, we showed that a firm's "grease money" bribery $x_{g}^{*}$ is a function of government service quality $K_{g}^{0}$, and its "protection money" bribery $x_{p}^{*}$ is a function of $K_{p}^{0}$. To the extent there are unobserved components in $K_{g}^{0}$ and $K_{p}^{0}$ that are not captured by their respective proxies, and with which firms within the same city (or district) and industry commonly deal, their expenditures $x_{g}^{*}$ and $x_{p}^{*}$ should be correlated. Because $x_{g}^{*}$ and $x_{p}^{*}$ are components of a firm's ETC, we expect that firms' ETC will also be correlated within the same group. ${ }^{32}$ We find that the averages are clearly correlated with a firm's ETC: the three instrumental variables are highly statistically significant in the first stage regression, and we will present evidence later that they appear to be strong instruments in the sense of Bound, Jager and Baker [6]. Moreover it is plausible that these instruments are not correlated with other firm-specific performance shocks after controlling for city, industry, and other firm characteristics. ${ }^{33}$

\subsection{Profit/Sales Ratio}

Table 3 reports the regression results of the effects of ETC on POS under various specifications. Column (1) is the basic OLS regression without including any endogenous variables. Most of the coefficient estimates are consistent with the predictions in Proposition 2 on firm performance. Indeed, firms with longer relationship with suppliers and clients (proxy for $K_{r}^{0}$ ) have higher POS. ${ }^{34}$

\footnotetext{
${ }^{30}$ District is one administrative level below the city, and there are typically 10 districts in each city. District government officials often have some discretion over the firm.

${ }^{31}$ The quadratic term for the district-industry average is not included because it does not have predictive power in the first stage regression. The three included instruments are all statistically significant in the first stage regression.

${ }^{32}$ These arguments are similar to those of Nevo [22], who argued that regional average prices (excluding the city being instrumented) can be used as an instrument for the city-level price because both prices respond to the product's common marginal cost.

${ }^{33}$ We have also experimented with using only the city-industry average of ETC and its square as instruments, and the qualitative conclusions remain similar.

${ }^{34}$ This finding suggests that private contracting relationships are very valuable to Chinese firms, which is likely attributable to the weak "contracting institutions" in China.
} 
Firms with better government service (proxy for $K_{g}^{0}$ ) also have higher POS, though the effect is not statistically significant. On the other hand, firms with higher lagged tax burden (proxy for $K_{p}^{0}$ ) has lower POS. All these findings are exactly in line with Proposition 2. Column (1) also shows that firms located in richer cities, as well as those that are larger, younger and more privately owned, have higher POS.

[Table 3 About Here]

Column (2) and (3) are respectively the OLS and GMM version of specification (9). Comparison of Column (1) and (2) shows that the addition of ETC only cause minor changes in the coefficient estimates of all other variables. The key result here is that ETC has a significantly negative effect on POS in the OLS specification (Column 2); however, as we instrument for ETC, the negative effect of ETC on POS is no longer significant (Column 3).

Column (4) reports the OLS version of specification (10). The coefficient estimates for previously included variables remain qualitatively stable. Notice from the comparison of Column (2) and (4), the effect of ETC becomes insignificant, though still negative, when we add interactions of ETC with $\mathbf{X}_{i}$. The OLS estimates of the coefficients $\gamma_{6}$ is interesting. They imply that the returns from ETC on POS are higher for firms that have better corporate governance (as reflected by "Private Ownership" and "Managerial Dismissal"), and for firms that are subject to more severer government expropriation (as proxied by "Tax Burden"). On the other hand, firms that have better baseline relationship with suppliers and clients (as proxied by "Years of Relationship") and better baseline government service quality (as proxied by "Government Help") experience lower, though statistically insignificant, returns of ETC on POS. These coefficient estimates are consistent with the implications of our model as described in detail in the beginning of Section 5 .

Column (5) is the GMM version of specification (10) and it is our preferred specification. The qualitative results from the GMM estimation are very similar to the OLS estimates as reported in Column (4). Column (6) is identical to Column (5) except that we use city dummies, instead of $\ln \left(G D P_{-} P C_{c}\right)$, as the city characteristics $X_{c}$. The qualitative results are again similar, with the exception that the returns to ETC on POS are lower for firms with higher "Private Ownership" in this specification.

It is worth noting that for the GMM specifications (Columns 3, 5, and 6), our instruments pass a variety of specification tests. The $p$-values for the over-identifying restrictions test, Hansen's $J$ test, are all greater than .10. The instruments thus appear to be orthogonal to the error term in Equation (9). The instruments are reasonably strong in the sense of Bound, Jager and Baker [6]: 
the $F$-test statistics for the test of the joint statistical significance of the excluded instruments are almost always greater than 10, and the marginal $R^{2}$ are also quite reasonable relative to those in Bound, Jager and Baker [6] that yield reasonable IV estimates. ${ }^{35}$

\subsection{TFP}

Table 4 reports the regression results of the effects of ETC on firm TFP. The dependent variable in these regressions is firm TFP, which is estimated from the residual in the regression of the logarithm of a firm's value-added on the logarithm of capital stock and the logarithm of the number of employees, allowing for industry specific Cobb-Douglas production function. ${ }^{36,} 37$

\section{[Tables 4 About Here]}

Column (1) reports the results from the basic OLS regression. The coefficient estimates for most of the control variables $\mathbf{Z}_{i}$ and $\mathbf{X}_{i}$ have the expected sign consistent with Proposition $2 .{ }^{38}$ In fact, the signs of the coefficient estimates are almost the same as those for POS as reported in Column (1) of Table 3, except for the two corporate governance variables. We find earlier that "Private Ownership" has a strong positive effect on firm POS (see Table 3), but here we find that "Private Ownership" does not appear to directly affect TFP, as the coefficient is negative but statistically insignificant; in contrast, we find earlier that "Managerial Dismissal" dummy has a statistically insignificant effect on POS, but here we find that it has a robust positive effect on TFP. Another difference between Column (1) in Table 3 and 4 is the significance of "Tax Burden": we find earlier that "Tax Burden" appears to have a statistically insignificant effect on POS, but here we find that it has a robust and negative effect on TFP.

Columns (2) and (3) are respectively the OLS and GMM version of specification (9). The coefficient estimates for previously included variables are similar to those in Column (1). Similar to the effect of ETC on POS reported in Table 3, we find that ETC has a strong negative effect on TFP: increasing ETC by one standard deviation (.062) reduces TFP by .29 and .46, based respectively on the OLS and GMM estimates.

\footnotetext{
${ }^{35}$ These comments are also applicable to GMM estimations reported in Table 4 and 6.

${ }^{36}$ The industry-specific coefficients of production factors tend to be significant, and most sectors exhibit constant or decreasing returns to scale.

${ }^{37}$ In Section 5.4 we report the regression results where TFP is estimated using alternative methods.

${ }^{38}$ Note that $\ln$ (Number of Employees) is not in the regressions because it has been used in estimating the firm's TFP.
} 
Column (4) and (5) are respectively the OLS and GMM version of specification (10). ${ }^{39}$ Similar to POS, we find that the effect of ETC on TFP becomes insignificant, though still negative, when we add interactions of ETC with $\mathbf{X}_{i}$. Column (4) and (5) indicate, again consistent with our model, that the private returns from ETC on TFP depend on the proxy variables for $K_{g}^{0}, K_{p}^{0}$ and $K_{r}^{0}$, as well as the corporate governance proxies. Remarkably the signs of the estimates for the coefficient in $\gamma_{6}$ for TFP are identical to those for POS. Column (6) reports the GMM regression that is identical to Column (5) except that city dummies are used instead of $\ln \left(G D P P_{-} P C_{c}\right)$ for city characteristics $X_{c}$. The results are qualitatively similar to those in Column (5).

\subsection{Marginal Effects of $\mathrm{X}_{i}$ on the Returns to ETC}

In this section we use the coefficient estimates from our preferred GMM estimation from Columns (5) in Tables 3 and 4 to summarize the marginal effects of ETC on POS and TFP, evaluated at the mean of the variable list $\mathbf{X}_{i}$. From specification (10), we have $\partial Y / \partial E T C=\gamma_{5}+\gamma_{6} \overline{\mathbf{X}}_{i}$.

\section{[Table 5 About Here]}

Panel A of Table 5 reports that, calculated at the means of all the $\mathbf{X}_{i}$ variables, increasing ETC by one percentage point will lower firms' POS by 4.43 percentage points and TFP by 22.02 percentage points. Both negative effects are statistically significant.

Panel B of Table 5 shows that the marginal effect of ETC on POS and TFP vary with the level of the variables in the list $\mathbf{X}_{i}$. In calculating the numbers in this panel, we take one variable at a time from the list $\mathbf{X}_{i}$ and set it at a level either higher or lower by one standard deviation from its mean, while holding other variables in the list $\mathbf{X}_{i}$ at their sample means. Comparing the effects reported in Rows (1) and (2) in Panel B with the corresponding numbers in Panel A, we see that firms with better corporate governance makes the negative return to ETC on both POS and TFP less negative, suggesting that a smaller component of ETC expenditures is managerial excesses in better-governed firms. Similarly Rows (3)-(5) indicates that the returns to ETC on both POS and TFP are less negative in firms that are in stronger need to strengthen the relationship with suppliers and clients, in firms that are more severely expropriated by government tax officials, and in those who experience lower baseline quality of government service. Most of these effects are statistically significant at lower than 10 percent level. These findings strongly support our theoretical prediction as detailed in the beginning of this section.

\footnotetext{
${ }^{39}$ In empirical implementation, we do not include ETC $\times$ "Sell to Other Provinces" dummy because it is never statistically significant in any specification.
} 


\subsection{Robustness}

[Table 6 About Here]

Table 6 presents GMM estimates for specification (10) with different measures of firm performance. Column (1) is the replicate of Column (5) in Table 3 with the exception that we drop the firms whose POS are in top and bottom 5 percentile. The results are almost identical to those reported in Column (5) of Table 3, thus they are not driven by outliers. Column (2)-(4) provide the estimates of ETC on TFP where TFP are estimated using alternative methods. The dependent variable in Column (2) is firms' TFP estimated from a translog value-added production function. ${ }^{40}$ The dependent variable in Column (3) is firms' TFP estimated from a Cobb-Douglas output production function. ${ }^{41}$ All three procedures of estimating TFP do not take into account the potential endogeneity of capital and labor with respect to productivity, a concern pointed out by Griliches and Mareisse [11]. Column (4) estimates firms' TFP using Levinsohn and Petrin's [17] proposed procedure to use intermediate inputs as instruments. ${ }^{42}$ The results are remarkably robust across Columns (2)-(5), both qualitatively and quantitatively, suggesting that our results are not sensitive to the particular way to estimate a firm's TFP.

To summarize, our analysis of the effects of ETC on firm performance provides strong support for our earlier findings about the composition of ETC. A significant portion of ETC is bribes to government officials, both for protection against government expropriation and in exchange for better government service. Accordingly, in situations with more severe government expropriation and a lower quality of government service, ETC tends to be higher and have a higher marginal return to firm performance. Managers also spend a portion of ETC on managerial excesses, as shown by the fact that ETC have a significantly negative effect on firm performance. These qualitative results are fairly robust to various functional forms and control variables.

\footnotetext{
${ }^{40}$ That is, a firm's TFP is the residual from industry specific regression of the logarithm of value-added on the logarithms of captial and labor as well as their quadratic terms.

${ }^{41}$ That is, a firm's TFP is the residual from industry-specific regression of the logarithm of its total sales (instead of value-added) on the logarithms of capital, labor and material inputs.

${ }^{42}$ We use the procedure suggested by Petrin, Levinsohn and Poi [25] to compute TFP within the value added Cobb-Douglas framework.
} 


\section{Conclusion}

We use large unique firm-level data sets from China to not only detect but also investigate the institutional causes of corruption among Chinese firms. We also examine how the private returns to firms from corruptive activities vary with institutional factors. Besides other detailed firm- and city-level information, the most important feature of our data set is that it contains objective information about Entertainment and Travel Costs (ETC), a standard expenditure item in the accounting book of Chinese firms that is widely used as the account to reimburse corruptive expenditures. We rely on the predictions from a simple but plausible model of managerial decisionmaking to identify components of ETC by examining how the total ETC responds to different environmental variables. In our empirical analysis we find strong evidence that firms' ETC consists of a mix that includes expenditures on government officials both as "grease money" and "protection money," expenditures to build relational capital with suppliers and clients, and managerial excesses. ETC overall has a significantly negative effect on firm performance (measured by both profitability and productivity), but its negative effect is much less pronounced for those firms located in cities with low quality government service, those subject to severe government expropriation and those who do not have strong relationship with their suppliers and clients. ${ }^{43}$ We also find that the negative impact of ETC is less pronounced in firms with better corporate governance.

Our empirical findings have important implications on the role of corruption in developing and transitional economies, and on how to curb corruption - a global priority as proposed by the Copenhagen Consensus (Rose-Ackerman [28]). First, despite the overall negative effect of ETC on firm performance, we find that components of ETC are spent productively as "grease money" and "protection money" and these components do generate positive private returns to firms. This is in stark contrast to the typical findings in the growth literature that corruption is correlated with lower economic growth (see, e.g., Mauro [19]). Our paper echoes the message of Acemoglu and Johnson [1] in demonstrating that corruption is affected by various institutional factors and as a result a negative overall correlation between corruption and firm performance does not necessarily indicate that all corruption components worsen firm performance. Second, while we find that parts of ETC expenditures have positive impact on firm performance, it does not necessarily imply that, these components of ETC expenditures are socially "efficient grease." Our finding implies that in economies with weak institutions firms may find it individually rational

\footnotetext{
${ }^{43}$ In the terminology of Acemoglu and Johnson [1], our findings suggest that Chinese firms react to both weak "property right institutions" and weak "contracting institutions" by ETC expenditures.
} 
to pay bribes and government officials find it individually rational to accept bribes. However, to evaluate the social efficiency of bribes, we have to take into account the possibility that bribing and government institutions are determined jointly in equilibrium. If, for example, government officials were intentionally lowering their service quality to extort more bribes, then banning corruption in the whole economy can improve the quality of government service (see Prendergast [26]).

\section{References}

[1] Acemoglu, Daron and Simon Johnson (2005). "Unbundling Institutions." Forthcoming, Journal of Political Economy.

[2] Ades, Alberto and Rafael Di Tella (1999). "Rents, Competition, and Corruption." American Economic Review, Vol. 89: 982-993.

[3] Bardhan, Pranab (1997). "Corruption and Development: A Review of the Issues." Journal of Economic Literature, Vol. 35, No. 3, 1320-1346.

[4] Bertrand, Marianne and Sendhil Mullainathan (2001). "Do People Mean What They Say? Implications for Subjective Survey Data." American Economic Review Papers and Proceedings, Vol. 91, No. 2: 67-72.

[5] Bodrock, Phil (2005). "The Shakedown.” Harvard Business Review, March 2005 Issue.

[6] Bound, John, David A. Jaeger and Regina M. Baker (1995). "Problems with Instrumental Variables Estimation When the Correlation Between the Instruments and the Endogenous Variable is Weak." Journal of the American Statistical Association, Vol. 90, 443-450.

[7] Cai, Hongbin, Qiao Liu and Geng Xiao (2005). "Does Competition Encourage Unethical Behavior? The Case of Corporate Profit Hiding in China." mimeo, UCLA.

[8] Di Tella, Rafael and Ernesto Schargrodsky (2003). "The Role of Wages and Auditing during a Crackdown on Corruption in the City of Buenos Aires." Journal of Law and Economics, Vol. 46, No. 1, 269-292

[9] Duggan, Mark and Steven D. Levitt (2002). "Winning Isn't Everything: Corruption in Sumo Wrestling." American Economic Review, Vol. 92, 1594-1605. 
[10] Fisman, Raymond and Jakob Svensson (2002). "Are Corruption and Taxation Really Harmful to Growth? Firm Level Evidence," World Bank Policy Research Working Paper Series No. 2485 .

[11] Griliches, Zvi and Mareisse, J. (1998). "Production Functions; The Search For Identification," in Econometrics and Economic Theory in the Twentieth Century: The Ragner Frisch Centennial Symposium, 169-203. Cambridge University Press.

[12] Hsieh, Chang-Tai and Enrico Moretti (2005). "Did Iraq Cheat the United Nations? Underpricing, Bribes, and the Oil for Food Program" NBER Working Paper 11202.

[13] Hu, Xingdou (2004). "Deter Big Corruption." www.huxingdou.com.cn/dafubai.htm.

[14] Johnson, Simon, Daniel Kaufmann, John McMillan and Christopher Woodruff (2000). "Why Do Firms Hide? Bribes and Unofficial Activity after Communism," Journal of Public Economics, Vol. 76: 495-520.

[15] Kaufmann, Daniel and Shang-Jin Wei (1998). "Does 'Grease' Money Speed Up the Wheels of Commerce?" World Bank Working Paper.

[16] Khwaja, Asim Ijaz and Atif Mian (2004). "Do Lenders Favor Politically Connected Firms? Rent Provision in an Emerging Financial Market.” mimeo, Harvard University Kennedy School of Government.

[17] Levinsohn, James and Amil Petrin (2003). "Estimating Production Functions Using Inputs to Control for Unobservables." Review of Economic Studies, Vol. 73, No. 2, 317-342.

[18] Lui, Francis (1985). "An Equilibrium Queuing Model of Bribery." Journal of Political Economy, Vol. 93, No. 4: 760-781.

[19] Mauro, Paolo (1995). "Corruption and Growth." Quarterly Journal of Economics, Vol. 110, No. 3: 681-712.

[20] Milgrom, Paul and Christina Shannon (1994). "Monotone Comparative Statics," Econometrica, Vol. 62, No. 1:157-180.

[21] Milgrom, Paul and Ilya R. Segal (2002). "Envelope Theorems for Arbitrary Choice Sets." Econometrica, Vol. 70, No. 2, 583-601. 
[22] Nevo, Aviv (2001). "Measuring Market Power in the Ready-To-Eat Cereal Industry." Econometrica, 69(2), 307-342.

[23] Olken, Benjamin (2005). "Corruption and the Costs of Redistribution: Micro Evidence from Indonesia." Forthcoming, Journal of Public Economics.

[24] Olken, Benjamin (2005). "Monitoring Corruption: Evidence from a Field Experiment in Indonesia." mimeo, Harvard University.

[25] Petrin, Amil, James Levinsohn, and Brian P. Poi. (2004). "Production Function Estimation in Stata Using Inputs to Control for Unobservables." Stata Journal Vol. 4, No. 2, 113-123.

[26] Prendergast, Canice (2002). "Investigating Corruption." mimeo, University of Chicago.

[27] Rose-Ackerman, Susan (1978). Corruption: A Study in Political Economy. Academic Press, New York, NY.

[28] Rose-Ackerman, Susan (2004). "The Challenge of Poor Governance and Corruption." in Global Crises, Global Solutions, edited by Bjorn Lomborg, Cambridge University Press.

[29] Treisman, Daniel (2000). "The Causes of Corruption: A Cross-National Study." Journal of Public Economics, Vol. 76: 399-457.

[30] Washington Post. "Common in China, Kickbacks Create Trouble for U.S. Companies at Home," by Peter S. Goodman, Monday, August 22, 2005, Page A01. 


\section{A Appendix: Proof of Proposition 1.}

Proof. Consider the manager's optimization problem (7). The first order condition with respect to $x_{c}$, assuming interior solution, is:

$$
\beta_{\pi} \Pi^{*}-\beta_{c} x_{c}^{*}=\ln \left[\tau \delta\left(\beta_{\pi}+\beta_{c}\right) V\right] .
$$

Using formula for the net profit (5), we can write $x_{c}^{*}$ as:

$$
x_{c}^{*}=\frac{\beta_{\pi} \varphi^{*}-\ln \left[\tau \delta\left(\beta_{\pi}+\beta_{c}\right) V\right]}{\beta_{\pi}+\beta_{c}}
$$

where $\varphi^{*}=\varphi\left(x_{r}^{*}, x_{g}^{*}, x_{p}^{*}\right)$ and

$$
\varphi\left(x_{r}, x_{g}, x_{p}\right) \equiv\left[1-t\left(x_{p} ; K_{p}^{0}, t_{0}\right)\right] q\left(K_{g}^{0}+a_{g} x_{g}, K_{r}^{0}+a_{r} x_{r}\right) Q-\left(x_{r}+x_{g}+x_{p}\right)
$$

is the firm's cash flow gross of the managerial excess $x_{c}^{*}$. Thus managerial excess increases in the firm's cash flow, decreases in monitoring intensity $\beta_{c}$, discount factor $\delta$ and continuation value of employment $V$.

Since $\left(x_{r}, x_{g}, x_{p}\right)$ appear in the manager's objective function $(7)$ only via net profit $\Pi$, their optimal levels will maximize the net profit $\Pi$ (or equivalently, maximize the cash flow $\varphi$ because $x_{c}$ does not interact with other components of ETC).

To prove A1 of Proposition 1, note that, for $i \in\{r, p, g\}$ when $a_{i}=0$, any positive level of $x_{i}$ has no effect on revenue but decreases profit. Thus it is optimal to choose $x_{i}^{*}=0$.

To prove A2, consider $i=g$ for example. When $a_{g}=0$, we know from A1 that $x_{g}^{*}=0$. Thus $K_{g}=K_{g}^{0}+a_{g} x_{g}^{*}=K_{g}^{0}$. Suppose $a_{r}$ and $a_{p}$ are positive and sufficiently large. Examining the net profit function (5) reveals that it is supermodular as a function of $x_{r}$ and $x_{p}$, and it satisfies the increasing difference property in $K_{g}=K_{g}^{0}$ (since $x_{g}^{*}=0$ ). Thus comparative statics results from Milgrom and Shannon [20] implies that $x_{r}^{*}$ and $x_{p}^{*}$ must be (weakly) increasing in $K_{g}^{0}$. Furthermore the optimal level of cash flow $\varphi^{*}$ described by (13) is increasing in $K_{g}^{0}$ (regardless of whether $a_{r}$ and $a_{p}$ are zero or not), as a result of the Generalized Envelope Theorem of Milgrom and Segal [21]. Thus, following (12) $x_{c}^{*}$ must always be increasing in $K_{g}^{0}$. Therefore, the total ETC, which is simply the sum $x_{c}^{*}+x_{r}^{*}+x_{p}^{*}+x_{g}^{*}$, is increasing in $K_{g}^{0}$. Assertion A3 is proved analogously.

B1 of Proposition 1 is obvious. To prove B2, again consider the case $i=g$. From B1, we know that when $a_{g}$ is positive and sufficiently large, the optimal level of $x_{g}$ is positive. Since $x_{g}>0$, we can use variable transformation $x_{g}=\left(K_{g}-K_{g}^{0}\right) / a_{g}$ to rewrite the firm's cash flow (13) as

$$
\varphi=\left[1-t\left(x_{p} ; K_{p}^{0}, t_{0}\right)\right] q\left(K_{g}, K_{r}\right) Q-\left(x_{r}+x_{p}\right)-\frac{K_{g}}{a_{g}}+\frac{K_{g}^{0}}{a_{g}} .
$$


Thus we can think of the manager's problem as choosing $x_{p}, x_{r}$ and $K_{g}$ to maximize $\varphi$ above. Note that $K_{g}^{0}$ enters (14) as a constant only. Thus, the optimal solution $x_{p}^{*}, x_{r}^{*}$ and $K_{g}^{*}$ must be independent of $K_{g}^{0}$. This has two implications. First, the optimal level of $x_{g}^{*}=\left(K_{g}^{*}-K_{g}^{0}\right) / a_{g}$ decreases linearly in $K_{g}^{0}$; second, the optimal level of cash flow can be written as $\varphi^{*}=A_{1}^{*}+K_{g}^{0} / a_{g}$ where $A_{1}^{*}$ is a term that is independent of $K_{g}^{0}$. This second implication, together with (12) implies that the optimal level of managerial excess $x_{c}^{*}$ can be written as

$$
x_{c}^{*}=A_{2}^{*}+\frac{\beta_{\pi}}{\beta_{\pi}+\beta_{c}} \frac{K_{g}^{0}}{a_{g}},
$$

where $A_{2}^{*}$ is a collection of terms that are independent of $K_{g}^{0}$. Summing up all components of ETC, we have

$$
x_{p}^{*}+x_{r}^{*}+x_{g}^{*}+x_{c}^{*}=A_{3}^{*}-\frac{\beta_{c}}{\beta_{\pi}+\beta_{c}} \frac{K_{g}^{0}}{a_{g}}
$$

where $A_{3}^{*}$ is a term independent of $K_{g}^{0}$. Thus the total ETC is decreasing in $K_{g}^{0}$. Assertion B3 is proved analogously.

\section{B Appendix: Proof of Proposition 2.}

Proof. As we argued in the proof of Proposition 1, the manager's optimal choice $x_{p}^{*}, x_{r}^{*}$ and $x_{g}^{*}$ maximize the firm's cash flow (13). Thus by Envelope Theorem, the firm's cash flow at these optimal choices $\varphi^{*}$ must be increasing in $K_{r}^{0}$ and $K_{g}^{0}$, and be decreasing in $K_{p}^{0}$. The firm's net profit at the optimal choices of $x_{r}^{*}, x_{g}^{*}, x_{p}^{*}$ and $x_{c}^{*}$ is simply the difference between $\varphi^{*}$ and $x_{c}^{*}$. By (12), we have

$$
\Pi^{*}=\varphi^{*}-x_{c}^{*}=\frac{\beta_{c} \varphi^{*}+\ln \left[\tau \delta\left(\beta_{\pi}+\beta_{c}\right) V\right]}{\beta_{\pi}+\beta_{c}} .
$$

Thus the firm's net profit under the manager's optimal choices is increasing in $K_{r}^{0}$ and $K_{g}^{0}$, but decreasing in $K_{p}^{0}$. 


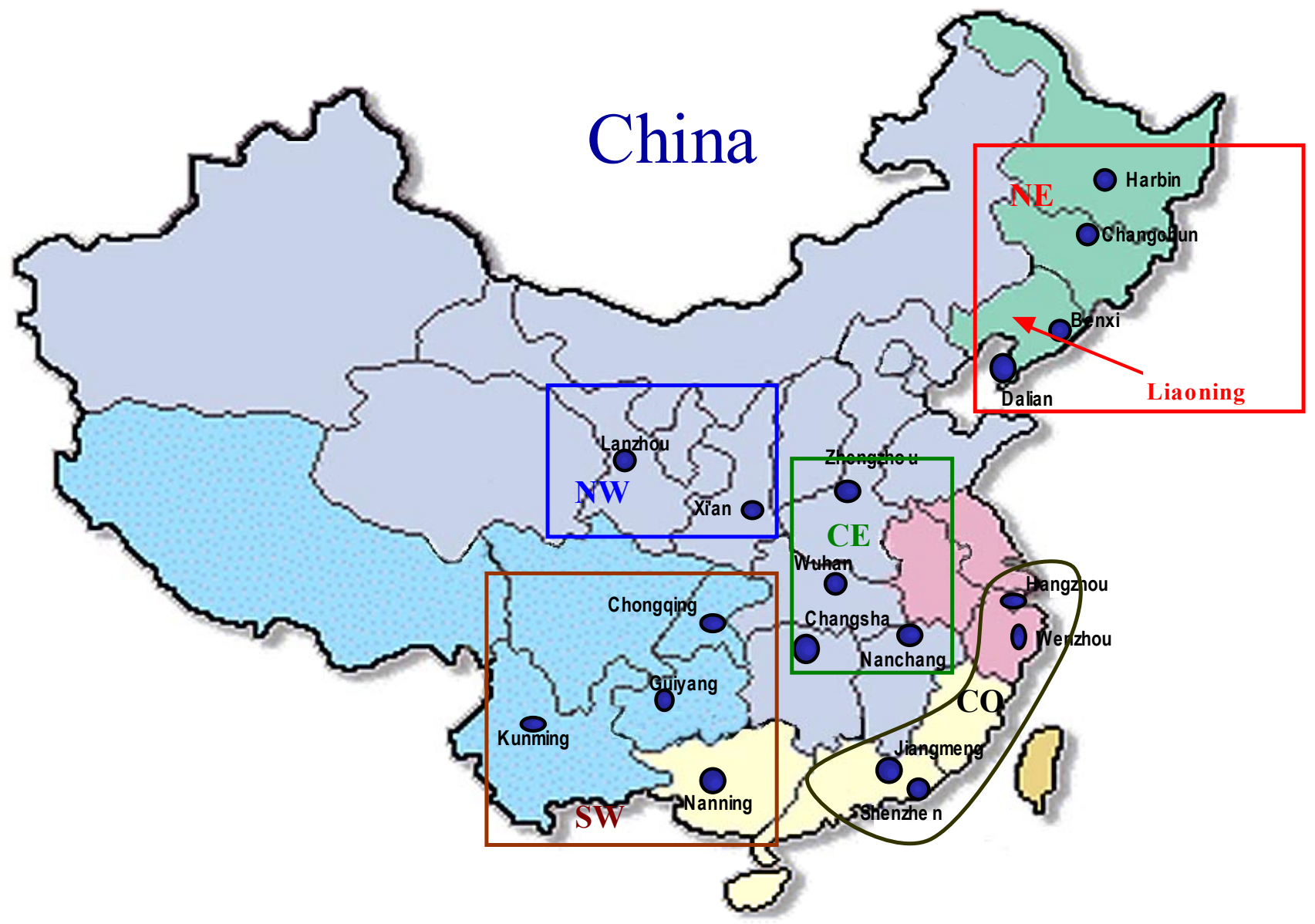

\section{Figure 1: The Geographic Coverage of the Surveys.}

Note: Only the 18 cities in the first survey are marked. The other 13 cities, not shown due to the space constraint, are all clustered around Benxi and Dalian in Liaoning province. The cities are grouped into five regions: Northeast (NE), Coastal (CO), Central (CE), Southwest (SW), and Northwest (NW). 


\section{A: ETC and Income}

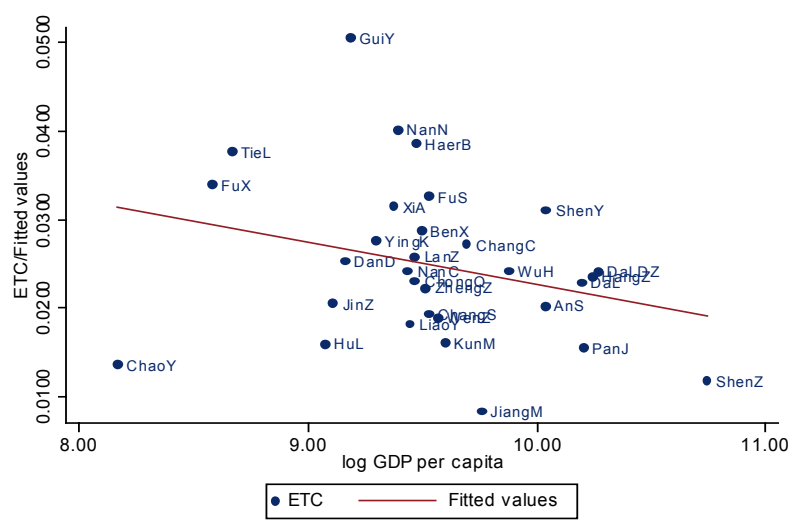

C: ETC and Tax Burden

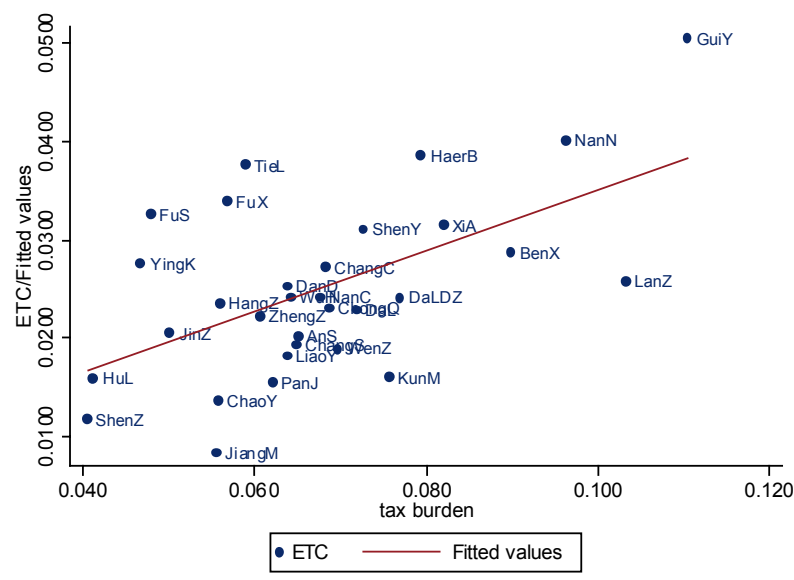

E: ETC and Private Ownership

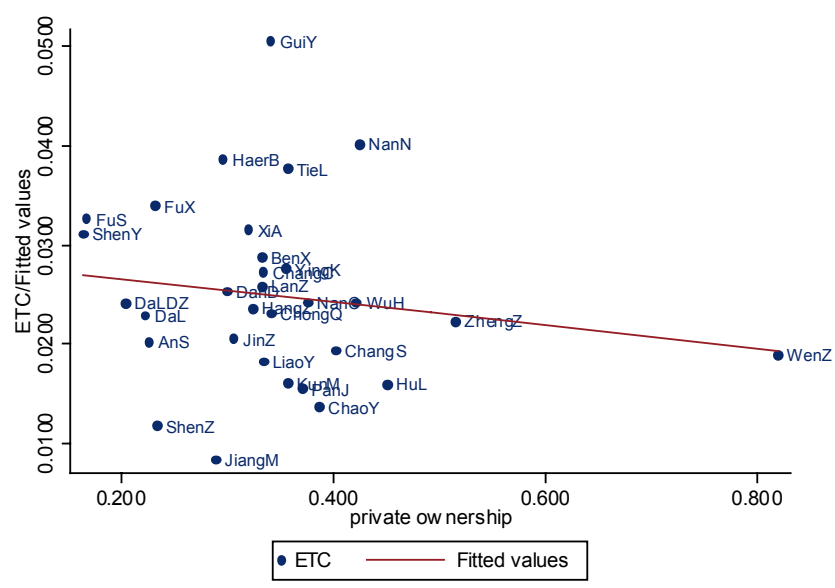

B: ETC and Government Help

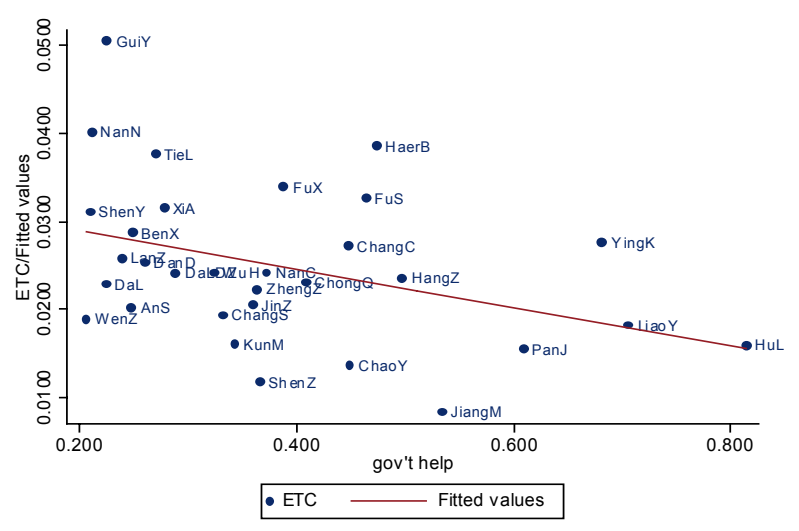

D: ETC and Years of Relationship

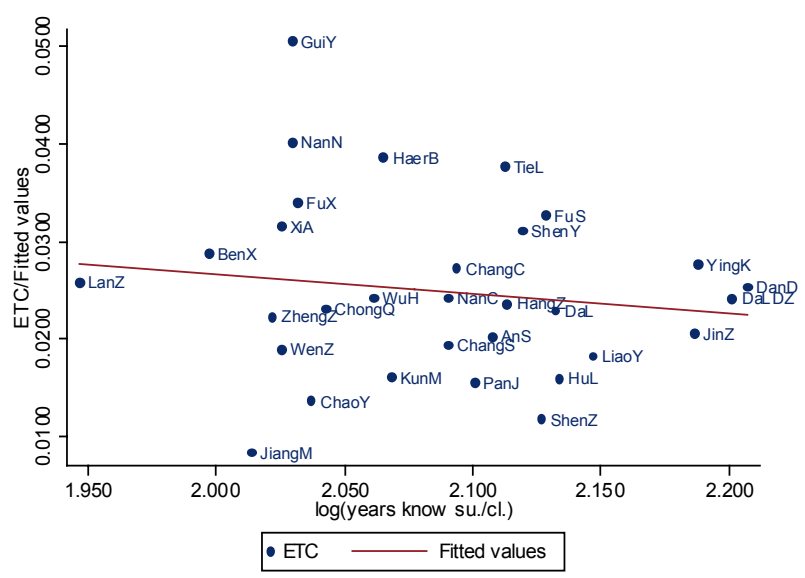

F: ETC and Managerial Dismissal

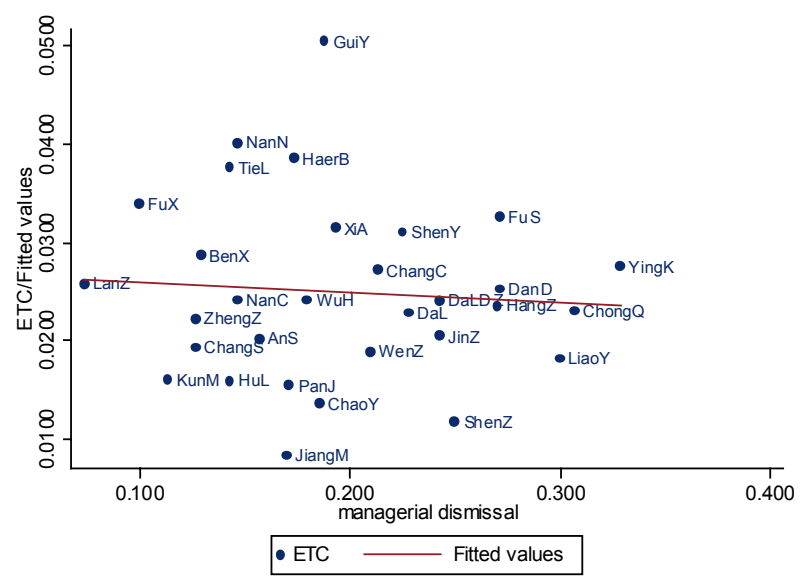

Figure 2: Relationship between Average ETC and Various Variables at the City Level. 
Table 1: Main Variables: Definitions and Descriptive Statistics.

\begin{tabular}{|c|c|c|c|}
\hline Variables & Definitions & Mean & $\begin{array}{l}\text { Standard } \\
\text { Deviation }\end{array}$ \\
\hline ETC & Entertainment and Travel Costs over Total Sales & 0.026 & 0.062 \\
\hline POS & Total Profits over Total Sales & -0.106 & 0.646 \\
\hline Sell to Other Provinces & A dummy variable for whether the firm sells to other provinces & 0.584 & 0.493 \\
\hline $\operatorname{Ln}\left(G D P \_P C\right)$ & Logarithm of GDP per capita in a city & 9.567 & 0.458 \\
\hline Ln(Number of Employees) & Logarithm of the number of employees & 4.866 & 1.483 \\
\hline Ln(Firm Age) & Logarithm of Firm Age plus one & 2.305 & 0.878 \\
\hline Private Ownership & Share of private ownership, both domestic and foreign & 0.350 & 0.455 \\
\hline Managerial Dismissal & $\begin{array}{l}\text { A dummy variable indicating if a general manager or deputy manager has } \\
\text { been fired in the previous four years }\end{array}$ & 0.187 & 0.390 \\
\hline Ln(Years of Relationship) & $\begin{array}{l}\text { The logarithm of the number of years that the firm has known its main } \\
\text { client plus the number of years the firm has known its main supplier }\end{array}$ & 2.073 & 0.333 \\
\hline Government Help & $\begin{array}{l}\text { The share of government officials that are helpful to the development of this } \\
\text { firm }\end{array}$ & 0.364 & 0.334 \\
\hline Tax Burden & The ratio of Total Tax over Total Sales in the previous year & 0.072 & 0.101 \\
\hline Ln(CEO_Worker Wage Ratio) & The logarithm of the ratio of the CEO's wage to the average worker wage & 1.004 & 0.752 \\
\hline Ln(CEO_Mid Wage Ratio) & $\begin{array}{l}\text { The logarithm of the ratio of the CEO's wage to the average wage of mid- } \\
\text { level managers }\end{array}$ & 0.604 & 0.608 \\
\hline
\end{tabular}

Note: The number of observations for various variables ranges from 3,104 to 3,468. 
Table 2: Determinants of ETC: OLS Regressions.

\begin{tabular}{|c|c|c|c|c|c|c|c|c|}
\hline & $(1)$ & $(2)$ & (3) & $(4)$ & $(5)$ & $(6)$ & $(7)$ & $(8)$ \\
\hline$\overline{L n\left(G D P \_P C\right)}$ & $\begin{array}{l}-0.005 \\
(0.002) * * *\end{array}$ & $\begin{array}{l}-0.005 \\
(0.002) * * *\end{array}$ & $\begin{array}{l}-0.004 \\
(0.002)^{* *}\end{array}$ & $\begin{array}{l}-0.005 \\
(0.002)^{* *}\end{array}$ & $\begin{array}{l}-0.004 \\
(0.002)^{* *}\end{array}$ & $\begin{array}{l}-0.004 \\
(0.002)^{* *}\end{array}$ & & \\
\hline Ln(Number of Employees) & $\begin{array}{l}-0.007 \\
(0.001)^{* * *}\end{array}$ & $\begin{array}{l}-0.007 \\
(0.001) * * *\end{array}$ & $\begin{array}{l}-0.006 \\
(0.001)^{* * *}\end{array}$ & $\begin{array}{l}-0.006 \\
(0.001)^{* * *}\end{array}$ & $\begin{array}{l}-0.006 \\
(0.001)^{* * *}\end{array}$ & $\begin{array}{l}-0.006 \\
(0.001)^{* * *}\end{array}$ & $\begin{array}{l}-0.005 \\
(0.001)^{* * *}\end{array}$ & $\begin{array}{l}-0.006 \\
(0.001)^{* * *}\end{array}$ \\
\hline Ln(Firm Age) & $\begin{array}{l}0.001 \\
(0.001)\end{array}$ & $\begin{array}{l}0.001 \\
(0.001)\end{array}$ & $\begin{array}{l}0.001 \\
(0.001)\end{array}$ & $\begin{array}{l}-0.001 \\
(0.001)\end{array}$ & $\begin{array}{l}0.001 \\
(0.001)\end{array}$ & $\begin{array}{l}0.000 \\
(0.001)\end{array}$ & $\begin{array}{l}0.000 \\
(0.001)\end{array}$ & $\begin{array}{l}0.001 \\
(0.002)\end{array}$ \\
\hline Sell to Other Provinces & $\begin{array}{l}0.005 \\
(0.002)^{* *}\end{array}$ & $\begin{array}{l}0.004 \\
(0.002)^{* *}\end{array}$ & $\begin{array}{l}0.005 \\
(0.002)^{* *}\end{array}$ & $\begin{array}{l}0.005 \\
(0.002)^{* *}\end{array}$ & $\begin{array}{l}0.005 \\
(0.002)^{* *}\end{array}$ & $\begin{array}{l}0.004 \\
(0.002)^{* *}\end{array}$ & $\begin{array}{l}0.004 \\
(0.002)^{*}\end{array}$ & $\begin{array}{l}0.005 \\
(0.003)^{*}\end{array}$ \\
\hline Private Ownership & & $\begin{array}{l}-0.002 \\
(0.002)\end{array}$ & & & $\begin{array}{l}-0.002 \\
(0.003)\end{array}$ & $\begin{array}{l}-0.001 \\
(0.002)\end{array}$ & $\begin{array}{l}0.000 \\
(0.003)\end{array}$ & $\begin{array}{l}0.001 \\
(0.003)\end{array}$ \\
\hline Managerial Dismissal & & $\begin{array}{l}0.008 \\
(0.002)^{* * *}\end{array}$ & & & $\begin{array}{l}0.008 \\
(0.003) * * *\end{array}$ & $\begin{array}{l}0.009 \\
(0.003)^{* * *}\end{array}$ & $\begin{array}{l}0.008 \\
(0.003)^{* * *}\end{array}$ & $\begin{array}{l}0.009 \\
(0.004)^{* *}\end{array}$ \\
\hline Ln(Years of Relationship) & & & $\begin{array}{l}-0.006 \\
(0.005)\end{array}$ & & $\begin{array}{l}-0.007 \\
(0.005)\end{array}$ & $\begin{array}{l}-0.006 \\
(0.005)\end{array}$ & $\begin{array}{l}-0.007 \\
(0.005)\end{array}$ & $\begin{array}{l}-0.006 \\
(0.006)\end{array}$ \\
\hline Government Help & & & & $\begin{array}{l}-0.006 \\
(0.003)^{* *}\end{array}$ & $\begin{array}{l}-0.006 \\
(0.003)^{* *}\end{array}$ & $\begin{array}{l}-0.006 \\
(0.003) *\end{array}$ & $\begin{array}{l}-0.004 \\
(0.003)\end{array}$ & $\begin{array}{l}-0.011 \\
(0.004)^{* *}\end{array}$ \\
\hline Tax Burden & & & & $\begin{array}{l}0.106 \\
(0.036)^{* * *}\end{array}$ & & $\begin{array}{l}0.098 \\
(0.038)^{* *}\end{array}$ & $\begin{array}{l}0.095 \\
(0.038)^{* *}\end{array}$ & $\begin{array}{l}0.096 \\
(0.045)^{* *}\end{array}$ \\
\hline Ln(CEO_Worker Wage Ratio) & & & & & & & & $\begin{array}{l}0.005 \\
(0.003)\end{array}$ \\
\hline Ln(CEO_Mid Wage Ratio) & & & & & & & & $\begin{array}{l}-0.005 \\
(0.004) \\
\end{array}$ \\
\hline Industry dummies & Yes & Yes & Yes & Yes & Yes & Yes & Yes & Yes \\
\hline City dummies & No & No & No & No & No & No & Yes & Yes \\
\hline R-squared & 0.04 & 0.04 & 0.04 & 0.07 & 0.05 & 0.07 & 0.09 & 0.09 \\
\hline Observations & 3426 & 3425 & 3080 & 3239 & 2934 & 2916 & 2916 & 1863 \\
\hline
\end{tabular}

Notes:

(1). The dependent variable is ETC;

(2). * ** and *** represent statistical significance at 10, 5 and 1 percent levels respectively;

(3) Standard deviations are in parentheses. 
Table 3: Effects of ETC on POS.

\begin{tabular}{|c|c|c|c|c|c|c|}
\hline & $\begin{array}{l}(1) \\
\end{array}$ & $\begin{array}{l}(2) \\
\end{array}$ & (3) & $\begin{array}{l}(4) \\
\end{array}$ & (5) & (6) \\
\hline$\overline{\text { Ln(GDP_PC) }}$ & $\begin{array}{l}0.057 \\
(0.023) * *\end{array}$ & $\begin{array}{l}0.035 \\
(0.019)^{*}\end{array}$ & $\begin{array}{l}0.026 \\
(0.013)^{* *}\end{array}$ & $\begin{array}{l}0.031 \\
(0.019)^{*}\end{array}$ & $\begin{array}{l}0.015 \\
(0.014)\end{array}$ & \\
\hline Ln(Number of Employees) & $\begin{array}{l}0.031 \\
(0.009) * * *\end{array}$ & $\begin{array}{l}0.023 \\
(0.009)^{* * *}\end{array}$ & $\begin{array}{l}0.019 \\
(0.010)^{* *}\end{array}$ & $\begin{array}{l}0.018 \\
(0.009)^{* *}\end{array}$ & $\begin{array}{l}0.005 \\
(0.013)\end{array}$ & $\begin{array}{l}0.014 \\
(0.013)\end{array}$ \\
\hline Ln(Firm Age) & $\begin{array}{l}-0.091 \\
(0.017)^{* * *}\end{array}$ & $\begin{array}{l}-0.093 \\
(0.016) * * *\end{array}$ & $\begin{array}{l}-0.083 \\
(0.010)^{* * *}\end{array}$ & $\begin{array}{l}-0.087 \\
(0.016)^{* * *}\end{array}$ & $\begin{array}{l}-0.074 \\
(0.011)^{* * *}\end{array}$ & $\begin{array}{l}-0.079 \\
(0.011)^{* * *}\end{array}$ \\
\hline Sell to Other Provinces & $\begin{array}{l}0.007 \\
(0.028)\end{array}$ & $\begin{array}{l}0.029 \\
(0.027)\end{array}$ & $\begin{array}{l}0.026 \\
(0.022)\end{array}$ & $\begin{array}{l}0.027 \\
(0.027)\end{array}$ & $\begin{array}{l}0.045 \\
(0.022)^{* *}\end{array}$ & $\begin{array}{l}0.023 \\
(0.021)\end{array}$ \\
\hline Private Ownership & $\begin{array}{l}0.128 \\
(0.025) * * *\end{array}$ & $\begin{array}{l}0.113 \\
(0.023) * * *\end{array}$ & $\begin{array}{l}0.101 \\
(0.016) * * *\end{array}$ & $\begin{array}{l}0.041 \\
(0.030)\end{array}$ & $\begin{array}{l}0.077 \\
(0.039)^{* *}\end{array}$ & $\begin{array}{l}0.109 \\
(0.041)^{* * *}\end{array}$ \\
\hline Managerial Dismissal & $\begin{array}{l}-0.006 \\
(0.025)\end{array}$ & $\begin{array}{l}0.018 \\
(0.022)\end{array}$ & $\begin{array}{l}0.021 \\
(0.020)\end{array}$ & $\begin{array}{l}-0.059 \\
(0.040)\end{array}$ & $\begin{array}{l}-0.053 \\
(0.029) *\end{array}$ & $\begin{array}{l}-0.049 \\
(0.027)^{*}\end{array}$ \\
\hline Ln(Years of Relationship) & $\begin{array}{l}0.063 \\
(0.033) *\end{array}$ & $\begin{array}{l}0.055 \\
(0.033) *\end{array}$ & $\begin{array}{l}0.069 \\
(0.026) * * *\end{array}$ & $\begin{array}{l}0.08 \\
(0.032)^{* *}\end{array}$ & $\begin{array}{l}0.143 \\
(0.039) * * *\end{array}$ & $\begin{array}{l}0.121 \\
(0.040)^{* * *}\end{array}$ \\
\hline Government Help & $\begin{array}{l}0.053 \\
(0.035)\end{array}$ & $\begin{array}{l}0.03 \\
(0.033)\end{array}$ & $\begin{array}{l}0.017 \\
(0.022)\end{array}$ & $\begin{array}{l}0.059 \\
(0.047)\end{array}$ & $\begin{array}{l}0.085 \\
(0.057)\end{array}$ & $\begin{array}{l}0.082 \\
(0.056)\end{array}$ \\
\hline Tax Burden & $\begin{array}{l}-0.18 \\
(0.225)\end{array}$ & $\begin{array}{l}-0.014 \\
(0.220)\end{array}$ & $\begin{array}{l}0.007 \\
(0.201)\end{array}$ & $\begin{array}{l}-0.109 \\
(0.230)\end{array}$ & $\begin{array}{l}-0.154 \\
(0.150)\end{array}$ & $\begin{array}{l}-0.17 \\
(0.149)\end{array}$ \\
\hline ETC & & $\begin{array}{l}-1.721 \\
(0.714)^{* *}\end{array}$ & $\begin{array}{l}-1.695 \\
(1.687)\end{array}$ & $\begin{array}{l}-2.477 \\
(1.765)\end{array}$ & $\begin{array}{l}1.422 \\
(1.712)\end{array}$ & $\begin{array}{l}1.879 \\
(1.747)\end{array}$ \\
\hline ETC * Private Ownership & & & & $\begin{array}{l}3.209 \\
(1.096) * * *\end{array}$ & $\begin{array}{l}0.854 \\
(1.524)\end{array}$ & $\begin{array}{l}-0.345 \\
(1.604)\end{array}$ \\
\hline ETC * Managerial Dismissal & & & & $\begin{array}{l}3.184 \\
(1.654) *\end{array}$ & $\begin{array}{l}3.6 \\
(1.474)^{* *}\end{array}$ & $\begin{array}{l}2.756 \\
(1.413)^{*}\end{array}$ \\
\hline ETC * Tax Burden & & & & $\begin{array}{l}2.467 \\
(1.420)^{*}\end{array}$ & $\begin{array}{l}4.414 \\
(2.743)\end{array}$ & $\begin{array}{l}2.239 \\
(2.963)\end{array}$ \\
\hline ETC* Ln(Years of Relationship) & & & & $\begin{array}{l}-0.742 \\
(0.824)\end{array}$ & $\begin{array}{l}-2.75 \\
(1.208)^{* *}\end{array}$ & $\begin{array}{l}-1.869 \\
(1.224)\end{array}$ \\
\hline ETC * Government Help & & & & $\begin{array}{l}-1.391 \\
(2.034)\end{array}$ & $\begin{array}{l}-3.947 \\
(2.487)\end{array}$ & $\begin{array}{l}-2.398 \\
(2.453)\end{array}$ \\
\hline Industry dummies? & Yes & Yes & Yes & Yes & Yes & Yes \\
\hline City dummies? & No & No & No & No & No & Yes \\
\hline R-squared & 0.04 & 0.06 & & 0.09 & & \\
\hline P-value of Hansen's J Test & & & 0.27 & & 0.722 & 0.563 \\
\hline F-test for excluded IVs & & & 12.82 & & 9.2 & 14.6 \\
\hline Partial R square * 100 & & & 0.63 & & 4.98 & 4.02 \\
\hline Observations & 2910 & 2905 & 2888 & 2905 & 2888 & 2888 \\
\hline
\end{tabular}

Notes:

(1). $* * *$ and $* * *$ represent statistical significance at the 10,5 and 1 percent levels respectively.

(2). Standard deviations are in parentheses for OLS specifications.

(3). For the GMM estimation, when ETC is not interacted with other variables, the instruments are the average ETC for the city-industry cell (excluding the firm itself) and its square, and the average ETC for the district-industry cell (excluding the firm itself). When ETC is interacted with other variables (say X), the instruments additionally include the three IVs for ETC interacted with X.

(4) The Hansen's J test, F test and partial R square for the GMM specifications are for the first stage ETC regression. The interaction-terms of ETC with other variables also have their first-stage regressions. The corresponding test statistics and partial R square are similar to those reported for ETC but not reported here. 
Table 4: Effects of ETC on TFP (Cobb-Douglas Specification).

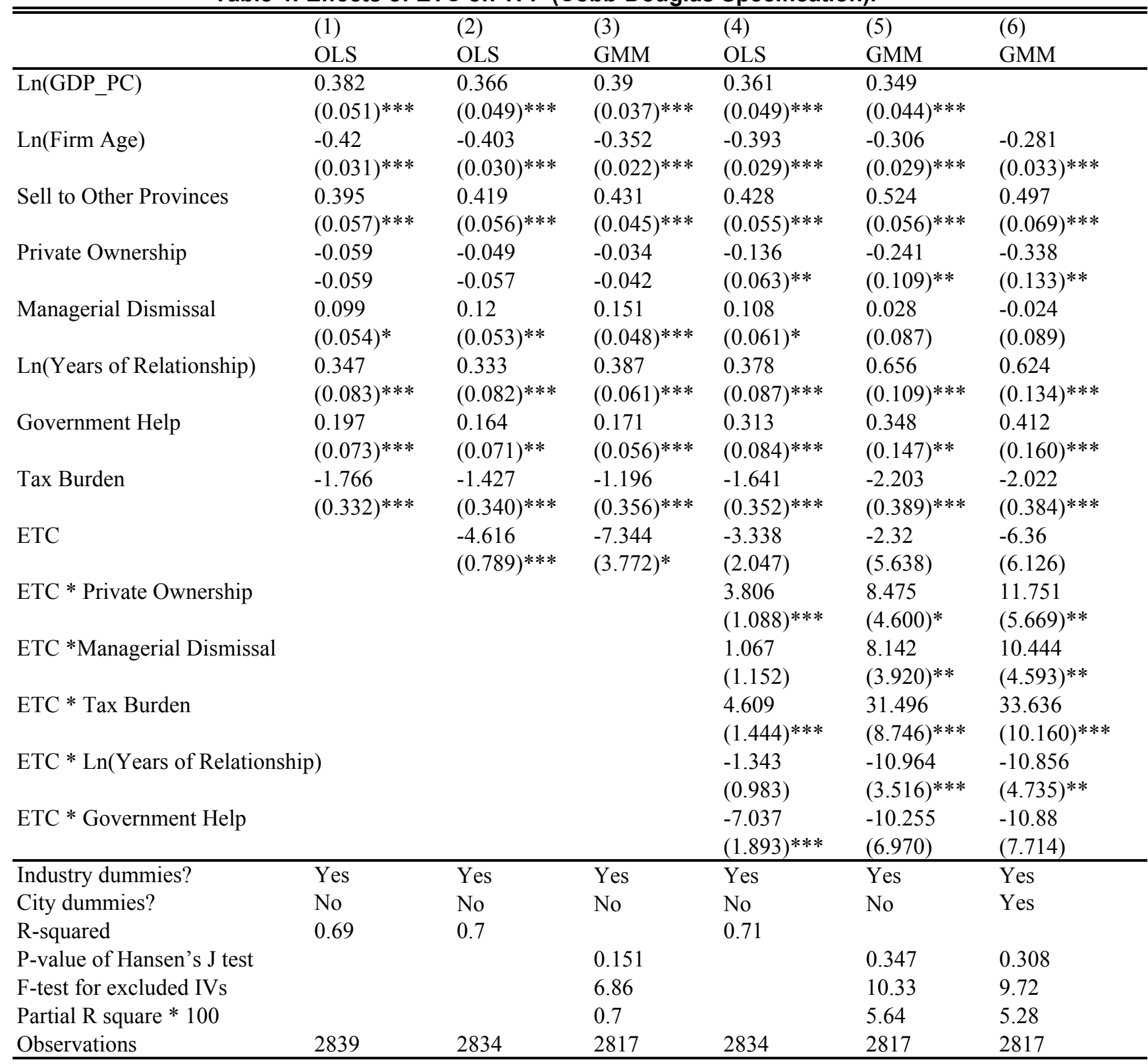

Notes:

(1). *,** and *** represent statistical significance at the 10,5 and 1 percent levels respectively.

(2). Standard deviations are in parentheses for OLS specifications.

(3). For the GMM estimation, when ETC is not interacted with other variables, the instruments are the average ETC for the city-industry cell (excluding the firm itself) and its square, and the average ETC for the district-industry cell (excluding the firm itself). When ETC is interacted with other variables (say X), the instruments additionally include the three IVs for ETC interacted with X.

(4) The Hansen's J test, F test and partial R square for the GMM specifications are for the first stage ETC regression. The interaction-terms of ETC with other variables also have their first-stage regressions. The corresponding test statistics and partial R square are similar to those reported for ETC but not reported here. 
Table 5: Marginal Effect of ETC on Firm Performance.

\begin{tabular}{lcc}
\hline \hline & $(1)$ & $(2)$ \\
& $\boldsymbol{T O S}$ & -22.02 \\
\hline Panel A: At the mean of all $\boldsymbol{X}$ variables & -4.43 & $(5.70)^{* * *}$ \\
Panel B: Otherwise at mean of the $\boldsymbol{X}$ variables, except: & $(2.36)^{*}$ & -18.17 \\
(1) Increase "Private Ownership" by one standard deviation & -4.04 & $(4.93)^{* * *}$ \\
(2) Increase "Managerial Dismissal" by one standard deviation & $(1.96)^{* *}$ & -18.85 \\
(3) Decrease "Ln(Years of Relationship)" by one standard deviation & -3.02 & $(4.85)^{* * *}$ \\
(4) Increase "Tax Burden" by one standard deviation & $-3.90)^{*}$ & -18.37 \\
(5) Decrease "Government Help" by one standard deviation & $(2.06)^{*}$ & $(4.89)^{* * *}$ \\
& -3.98 & -18.84 \\
\hline \hline
\end{tabular}

Notes:

(1). Columns 1 and 2 are based on the estimates of columns (5) of Tables 3 and 4, respectively.

(2). Standard errors are in parenthesis.

(3). $* * *$, and $* * *$ represent statistical significance at the 10,5 and 1 percent levels respectively.

(4). See the text for how the marginal effects in Panel B are calculated. 
Table 6: Effect of ETC on Firm Performance: Robustness Checks.
(1)
(2)
(3)
(4)

\begin{tabular}{lcccc} 
Firm Performance Measure & POS & TFP & TFP & TFP \\
& & Translog Value & Cobb-Douglas & \\
How is TFP estimated? & & Added & Output & Levinsohn-Petrin \\
Ln(GDP_PC) & 0.014 & 0.346 & 0.326 & 0.384 \\
& $(0.014)$ & $(0.044)^{* * *}$ & $(0.042)^{* * *}$ & $(0.057)^{* * *}$ \\
Ln(Firm Age) & -0.073 & -0.295 & -0.312 & -0.246 \\
& $(0.011)^{* * *}$ & $(0.029)^{* * *}$ & $(0.024)^{* * *}$ & $(0.029)^{* * *}$ \\
Sell to Other Provinces & 0.048 & 0.513 & 0.421 & 0.599 \\
& $(0.022)^{* *}$ & $(0.055)^{* * *}$ & $(0.051)^{* * *}$ & $(0.057)^{* * *}$ \\
Private Ownership & 0.078 & -0.228 & -0.124 & -0.383 \\
& $(0.040)^{* *}$ & $(0.110)^{* *}$ & $(0.113)$ & $(0.112)^{* * *}$ \\
Managerial Dismissal & -0.057 & 0.03 & 0.01 & 0.069 \\
& $(0.029)^{*}$ & $(0.086)$ & $(0.081)$ & $(0.105)$ \\
Ln(Years of Relationship) & 0.146 & 0.669 & 0.614 & 0.745 \\
& $(0.040)^{* * *}$ & $(0.108)^{* * *}$ & $(0.099)^{* * *}$ & $(0.111)^{* * *}$ \\
Government Help & 0.096 & 0.287 & 0.38 & 0.431 \\
& $(0.058)^{*}$ & $(0.144)^{* *}$ & $(0.156)^{* *}$ & $(0.175)^{* *}$ \\
Tax Burden & -0.122 & -2.272 & -2.512 & -2.507 \\
& $(0.152)$ & $(0.382)^{* * *}$ & $(0.289)^{* * *}$ & $(0.464)^{* * *}$ \\
ETC & 1.688 & -1.634 & 3.482 & -8.153 \\
& $(1.743)$ & $(5.546)$ & $(5.727)$ & $(6.453)$ \\
ETC * Private Ownership & 0.689 & 8.271 & 4.119 & 16.154 \\
& $(1.556)$ & $(4.625)^{*}$ & $(4.791)$ & $(5.290)^{* * *}$ \\
ETC * Managerial Dismissal & 3.881 & 7.435 & 8.301 & 10.314 \\
& $(1.503)^{* * *}$ & $(3.832)^{*}$ & $(3.329)^{* *}$ & $(4.527)^{* *}$ \\
ETC * Tax Burden & 4.339 & 33.024 & 26.95 & 41.211 \\
& $(2.795)$ & $(8.992)^{* * *}$ & $(5.696)^{* * *}$ & $(8.274)^{* * *}$ \\
ETC * Ln(Years of Relationship) & -2.915 & -11.723 & -12.589 & -14.09 \\
& $(1.226)^{* *}$ & $(3.560)^{* * *}$ & $(3.212)^{* * *}$ & $(3.770)^{* * *}$ \\
ETC * Government Help & -4.672 & -7.057 & -10.837 & -13.994 \\
& $(2.548)^{*}$ & $(6.783)$ & $(7.356)$ & $(8.483)^{*}$ \\
\hline Industry dummies & Yes & Yes & Yes & Yes \\
Hansen's J statistics & 0.716 & 0.528 & 0.213 & 0.147 \\
Observations & 2605 & 2817 & 2771 & 2817 \\
\hline \hline
\end{tabular}

Notes:

(1). All columns are GMM estimation results.

(2). Column (1) is identical to Column (5) in Table 3 except that it excludes firms in the top and bottom 5 percentile of POS.

(3). * ${ }^{* *}$, and $* * *$ represent statistical significance at the 10,5 and 1 percent levels respectively.

(4). Standard errors are in parenthesis.

(5). For colums (2)-(4), we also control for all e related factors for production functions whenever it applies, including $\operatorname{Ln}($ Capital), Ln(Number of Employees), Ln(Material Inputs). See the text for more details.

(6). For the GMM estimation, when ETC is not interacted with other variables, the instruments are the average ETC for the city-industry cell (excluding the firm itself) and its square, and the average ETC for the district-industry cell (excluding the firm itself). When ETC is interacted with other variables (say X), the instruments additionally include the two IVs associated with ETC interacted with X. 
Table A1. Averages of Key Variables Across Cities.

\begin{tabular}{|c|c|c|c|c|c|c|c|c|c|}
\hline City & Ln(GDP_PC) & ETC & $\begin{array}{l}\text { Tax Burden in the } \\
\text { Previous Year }\end{array}$ & $\begin{array}{c}\text { Managerial } \\
\text { Dismissal }\end{array}$ & $\begin{array}{c}\text { Years of } \\
\text { Relationship }\end{array}$ & $\begin{array}{c}\text { Private } \\
\text { Ownership }\end{array}$ & $\begin{array}{c}\text { Government } \\
\text { Help }\end{array}$ & POS & TFP \\
\hline Chaoyang & 8.167 & 0.014 & 0.054 & 0.186 & 7.668 & 0.387 & 0.449 & -0.026 & 0.302 \\
\hline Fuxin & 8.582 & 0.034 & 0.058 & 0.100 & 7.627 & 0.233 & 0.389 & -0.227 & -0.316 \\
\hline Tieling & 8.670 & 0.038 & 0.057 & 0.143 & 8.268 & 0.358 & 0.271 & -0.126 & -0.149 \\
\hline Huludao & 9.077 & 0.016 & 0.040 & 0.143 & 8.447 & 0.451 & 0.815 & -0.174 & 0.016 \\
\hline Jinzou & 9.111 & 0.021 & 0.051 & 0.243 & 8.904 & 0.307 & 0.360 & -0.068 & 0.305 \\
\hline Dandong & 9.163 & 0.025 & 0.058 & 0.271 & 9.090 & 0.301 & 0.261 & -0.076 & 0.593 \\
\hline Guiyang & 9.189 & 0.050 & 0.109 & 0.188 & 7.613 & 0.344 & 0.226 & -0.096 & -0.269 \\
\hline Yingkou & 9.301 & 0.028 & 0.042 & 0.329 & 8.918 & 0.355 & 0.682 & -0.049 & 0.176 \\
\hline Xi'an & 9.375 & 0.032 & 0.082 & 0.193 & 7.582 & 0.324 & 0.279 & -0.047 & -0.037 \\
\hline Nanning & 9.394 & 0.040 & 0.108 & 0.147 & 7.613 & 0.435 & 0.212 & -0.204 & -0.152 \\
\hline Nanchang & 9.438 & 0.024 & 0.076 & 0.147 & 8.090 & 0.378 & 0.373 & -0.004 & -0.024 \\
\hline Liaoyang & 9.447 & 0.018 & 0.059 & 0.300 & 8.559 & 0.335 & 0.707 & -0.078 & -0.049 \\
\hline Lanzhou & 9.469 & 0.026 & 0.105 & 0.074 & 7.005 & 0.336 & 0.239 & -0.078 & -0.730 \\
\hline Chongqing & 9.469 & 0.023 & 0.069 & 0.307 & 7.713 & 0.342 & 0.409 & -0.107 & -0.069 \\
\hline Haerbin & 9.472 & 0.039 & 0.082 & 0.173 & 7.887 & 0.299 & 0.474 & -0.196 & -0.381 \\
\hline Benxi & 9.497 & 0.029 & 0.092 & 0.129 & 7.367 & 0.332 & 0.249 & -0.255 & -0.646 \\
\hline Zhengzhou & 9.517 & 0.022 & 0.062 & 0.127 & 7.552 & 0.521 & 0.364 & -0.139 & -0.111 \\
\hline Fushun & 9.528 & 0.033 & 0.050 & 0.271 & 8.404 & 0.168 & 0.465 & -0.135 & 0.223 \\
\hline Changsha & 9.529 & 0.019 & 0.069 & 0.127 & 8.090 & 0.406 & 0.332 & -0.163 & -0.017 \\
\hline Wenzou & 9.566 & 0.019 & 0.065 & 0.210 & 7.580 & 0.813 & 0.206 & 0.041 & 0.475 \\
\hline Kunming & 9.602 & 0.016 & 0.073 & 0.113 & 7.912 & 0.367 & 0.343 & -0.240 & -0.425 \\
\hline Changchun & 9.694 & 0.027 & 0.067 & 0.213 & 8.115 & 0.332 & 0.448 & -0.098 & 0.094 \\
\hline Jiangmeng & 9.761 & 0.008 & 0.058 & 0.170 & 7.490 & 0.297 & 0.535 & -0.168 & 0.095 \\
\hline Wuhan & 9.881 & 0.024 & 0.066 & 0.180 & 7.856 & 0.428 & 0.325 & -0.069 & 0.068 \\
\hline Anshan & 10.041 & 0.020 & 0.069 & 0.157 & 8.230 & 0.227 & 0.248 & -0.239 & 0.203 \\
\hline Shenyang & 10.042 & 0.031 & 0.073 & 0.225 & 8.329 & 0.165 & 0.210 & -0.157 & 0.163 \\
\hline Dalian & 10.197 & 0.023 & 0.074 & 0.228 & 8.434 & 0.223 & 0.225 & -0.018 & 0.359 \\
\hline Panjin & 10.206 & 0.015 & 0.067 & 0.171 & 8.173 & 0.371 & 0.609 & -0.001 & 0.699 \\
\hline Hangzhou & 10.245 & 0.024 & 0.061 & 0.270 & 8.279 & 0.338 & 0.498 & 0.002 & 0.727 \\
\hline Dalian Zone & 10.270 & 0.024 & 0.077 & 0.243 & 9.038 & 0.206 & 0.289 & -0.016 & 0.533 \\
\hline Shenzhen & 10.745 & 0.012 & 0.046 & 0.250 & 8.389 & 0.237 & 0.367 & 0.052 & 0.735 \\
\hline
\end{tabular}

Note: TFP is calcuated from the Cobb-Douglas specification. 